Article

\title{
Effects of Ultrasonication Time on the Properties of Polyvinyl Alcohol/Sodium Carboxymethyl Cellulose/Nano-ZnO/Multilayer Graphene Nanoplatelet Composite Films
}

\author{
Tengteng Ji ${ }^{1,2,+}$, Rong Zhang ${ }^{1,2,+}$, Xiaorong Dong ${ }^{1}$, Dur E Sameen ${ }^{1}$, Saeed Ahmed ${ }^{1}$, \\ Suqing $\mathrm{Li}^{1, *+\dagger}$ and Yaowen Liu ${ }^{1,2, *}$ \\ 1 College of Food Science, Sichuan Agricultural University, Ya'an 625014, China; jtt5881@163.com (T.J.); \\ zhangronglzy@163.com (R.Z.); dxr1175752318@163.com (X.D.); sameen0388@gmail.com (D.E.S.); \\ saeedahmedM1993@gmail.com (S.A.) \\ 2 School of Materials Science and Engineering, Southwest Jiaotong University, Chengdu 610031, China \\ * Correspondence: 1sq03_2001@163.com (S.L.); lyw@my.swjtu.edu.cn (Y.L.); Tel.: +86-835-8763-4068 (Y.L.) \\ + These authors contributed equally to the work.
}

Received: 13 August 2020; Accepted: 4 September 2020; Published: 10 September 2020

\begin{abstract}
Ultrasonication-assisted solution casting was used to prepare polyvinyl alcohol (PVA)/sodium carboxymethyl cellulose (CMC)/nano-ZnO/multilayer graphene nanoplatelet $(x \mathrm{GnP})$ composite films; the performances (mechanical properties, water vapor permeability (WVP), biodegradability and antibacterial activity) of these films were investigated as a function of the ZnO NPs: $x \mathrm{GnP}$ mass ratio and ultrasonication time. Intermolecular interactions among ZnO NPs, $x \mathrm{GnP}$ and the PVA/CMC matrix were shown to improve WVP, while X-ray diffraction and scanning electron microscopy analyses revealed that the internal reticular structure of ultrasound-treated $\mathrm{PVA} / \mathrm{CMC} / \mathrm{ZnO} \mathrm{NPs} / x \mathrm{GnP}$ composite films was in a fluffier state than that of the untreated composite films and the PVA/CMC film. The incorporation of ZnO NPs and $x \mathrm{GnP}$ into the composite film reduced its tensile strength and elongation at break, and increased antibacterial activity and biodegradability. In addition, we carried out the experiment of strawberry preservation and measured weight loss ratio, firmness, content of total soluble solids and titration acid. Finally, the composite film of 7:3 had the best preservation effect on strawberries. Thus, the obtained results paved the way to develop novel biodegradable composite films with antimicrobial activity for a wide range of applications.
\end{abstract}

Keywords: carboxymethyl cellulose; zinc oxide; multilayer graphene nanoplatelets

\section{Introduction}

Nowadays, most food packaging materials mainly consist of petrochemical-based polymers because they are convenient, low-cost and have excellent barrier performances [1]. However, it is commonly accepted that those nonbiodegradable materials will cause irreversible environmental contaminations both in the long- and short-term, and are harmful to public health [2]. Therefore, it is crucial to develop degradable, antibacterial and cheap polymer films for food packaging.

Some of the materials that have been used for the preparation of packaging materials which have biodegradable properties are starch, PVA and polylactic acid (PLA) [3]. Among these, PVA is a non-toxic, highly crystalline and water-soluble polymer that has good film-forming and high hydrophilic properties [2]. PVA can also supply hydroxyl groups on the surface of nanofibers. The hydroxyl groups can also serve to adsorb heavy metal ions [4]. Because of the hydrophilic hydroxyl group $(-\mathrm{OH})$ in the molecule, the water resistance of PVA film can be improved if the hydroxyl 
group can be closed properly and connected to the water-resistant group. PVA is often combined with cellulose and its derivatives, such as carboxymethyl cellulose (CMC), to prepare composites. CMC has abundant carboxyl groups and is therefore sensitive to water, aiding its absorption by PVA, while strong hydrogen bonding between the hydroxyl groups of PVA and CMC due to blending results in remarkable mechanical properties. PVA/CMC blends are considered to be a useful matrix for improving the solid polymer, and have many potential applications $[5,6]$. However, pure PVA/CMC composite films feature low water resistance and have no resistance to pathogens. Coincidentally, many studies have shown that when inorganic NPs are added to a polymer, their antibacterial properties are greatly improved. Zhong et al. [7] attempted to fabricate a multi-functional ZnO NPs/CS composite with enhanced biosafety in an efficient and low-cost way, which has potential applications as an antibacterial, UV-shielding or dye water-treatment agent. Currently, ZnO NPs is one of the five zinc compounds that are listed as generally recognized as safe (GRAS) materials by the U.S. Food and Drug Administration [8]. ZnO NPs possess many advantages, such as being non-toxic, allowing cheap and easy synthesis of semiconductor materials, having high photocatalytic activity, good chemical stability and resistance to light corrosion, and are easily doped, and so on [9], whereas their mechanical properties experience deterioration due to the NP surface effect and interfacial action [9].

In addition, numerous metal oxides and NPs have been compounded with graphene sheet layers to obtain superior composites, as the addition of appropriate amounts of graphene to polymers can significantly improve their mechanical properties through the effects of van der Waals forces. Parameswaranpillai et al. [10] have shown that the incorporation of exfoliated graphene nanoplatelets $(x \mathrm{GnP})$ into ternary PP/PS/SEBS blends significantly improves the tensile modulus and elongation at break of ternary. The ease of production and high chemical inertness of graphene make it a promising filler, although its widespread use is hindered by its poor dispersibility in both organic and inorganic solvents. In addition, the non-uniform distribution of nanofillers in the polymer matrix may result in mechanical property deterioration and pore formation [11].

Ultrasonication is widely employed in the field of material design and engineering, as its heating, mechanical, super-mixing and cavitation effects facilitate the breakage of the original hydrogen bonds and hydrophobic bonds in the medium, and thus promote the formation and exposure of more reaction centers [12]. In turn, this accelerates chemical reactions and allows macromolecules to recombine and form a variety of nonpolar bonds. Moreover, ultrasonication further improves material solubility, and makes films adopt more compact network structures [13]. The intensity of the effect of using a direct ultrasonication device (probe) in solution is far greater than that of mechanical agitation, as the former allows the particles in the solution to be uniformly distributed on a macroscopic scale, while cavitation aids further particle homogenization on a microscopic scale [14]. Hence, the use of a direct ultrasonication device helps one to avoid nanofiber agglomeration. However, the effect of ultrasonication time on the physicochemical properties of composite films remains underexplored. Herein, to address this knowledge gap, we fabricated PVA/CMC/nano ZnO NPs/multilayer graphene nanoplatelet $(x \mathrm{GnP})$ films using a combination of ultrasonication and solution casting methods, and explored the influence of the $\mathrm{ZnO} N \mathrm{Ns}: x \mathrm{GnP}$ mass ratio and ultrasonication time on film properties.

\section{Materials and Methods}

\subsection{Materials}

PVA $(\mathrm{Mw}=7.6 \mathrm{kDa}, \mathrm{Mw} / \mathrm{Mn}=1.32,1700$ degree of polymerization and 99\% hydrolyzation $)$ was procured from Shenzhen Esun Industrial Co., Ltd. (Shenzhen, China). Analytical grade CMC (300-800 mPa.s) was purchased from Shanghai Chemical Agents Co., Ltd. (Shanghai, China) and used as received. $\mathrm{ZnO} N P s$ (average size $=30 \mathrm{~nm}$ ) were purchased from Sigma-Aldrich. $x \mathrm{GnP}$ (multilayer graphene nanoplatelet, with strong toughness and good antibacterial properties) was sourced from Suzhou Yougao Nanomaterials Co., Ltd. 


\subsection{Preparation of PVA/CMC Films}

PVA/CMC films were obtained by solution casting. PVA $(10 \mathrm{~g})$ and CMC $(1 \mathrm{~g})$ were dissolved in distilled water $(200 \mathrm{~mL})$ upon magnetic stirring at $80{ }^{\circ} \mathrm{C}$ to afford a PVA/CMC mixed solution. This solution was split into five portions and subjected to an ultrasonic processor (Hielscher UP400S, $400 \mathrm{~W}, 24 \mathrm{kHz}$, Labsun China, Shanghai, China), ultrasonicated for 0, 15, 30, 45 and $60 \mathrm{~min}$, and the final PVA/CMC solutions were poured onto plastic plates, and extended to obtain uniform initial films that were oven-dried at $30^{\circ} \mathrm{C}$ for $4 \mathrm{~h}$. After the solvent was completely eliminated, the plastic plates with films were further dried overnight at room temperature.

\subsection{Preparation of $P V A / C M C / Z n O N P s / x G n P$ Composite Films}

$\mathrm{ZnO}$ NPs and $x \mathrm{GnP}$ (The total mass of ZnO NPs and $x \mathrm{GnP}$ is $10 \%$ of that of PVA and CMC; $\mathrm{mZnO}$ NPs:mG $=10: 0,9: 1,7: 3,5: 5,3: 7,1: 9$ and 0:10) were suspended in distilled water (200 mL), and the suspension was placed in an ultrasonic bath for $60 \mathrm{~min}$. Next, PVA $(10 \mathrm{~g})$ and CMC $(1 \mathrm{~g})$ were dissolved in the suspension using magnetic stirring at $80^{\circ} \mathrm{C}$. The obtained solution was processed using the process described for pure PVA/CMC films to obtain PVA/CMC/ZnO NPs/ $x \mathrm{GnP}$ composite films.

\subsection{Swelling Capacity and Solubility}

This process was slightly modified according to the method of Yan et al. [15]. The films were cut into $3 \mathrm{~cm} \times 3 \mathrm{~cm}$ pieces for the determination of solubility and swelling degree. The pieces were dried at $105{ }^{\circ} \mathrm{C}$ to a constant weight to obtain the initial dry mass $\left(M_{1}\right)$. Then, they were placed in $100 \mathrm{~mL}$ beakers with $50 \mathrm{~mL}$ distilled water covered with plastic wraps and stored at $25^{\circ} \mathrm{C}$ for $24 \mathrm{~h}$. Next, the films were dried superficially with filter papers and dried at $105^{\circ} \mathrm{C}$ to a constant weight to obtain the final dry mass $\left(M_{2}\right)$. Then, the solubility was calculated using the following equation:

$$
\text { solubility }=\frac{M_{1}-M_{2}}{M_{1}},
$$

The films were put into $50 \mathrm{~mL}$ beakers with $30 \mathrm{~mL}$ distilled water for $24 \mathrm{~h}$ at $25^{\circ} \mathrm{C}$ after weighing the films $\left(M_{1}\right)$. The wet films were then dried superficially with filter papers, followed by weighing the wet films $\left(M_{2}\right)$. The swelling degree was calculated using the following equation:

$$
\text { swelling }=\frac{M_{2}-M_{1}}{M_{1}}
$$

For each film, three parallel samples of strips were measured, and the average was used as the final result.

\subsection{Scanning Electron Microscopy (SEM)}

Film surface morphology was analyzed by SEM (TOPCON ABT-150 S, COXEM company, Beijing, China). Prior to imaging, the samples were hung on metal grids and coated with gold vapor under vacuum [16].

\subsection{Attenuated Total Reflectance-Fourier Transform Infrared (ATR-FTIR) Spectroscopy}

ATR-FTIR (Prestige-21, Shimazu International Trade (Shanghai) Co., Ltd., Shanghai, China) spectra were recorded over a wavenumber range of $650-4000 \mathrm{~cm}^{-1}$ at room temperature, a resolution of $4 \mathrm{~cm}^{-1}$, and a scan frequency of $32 \mathrm{~s}^{-1}$ to identify major functional groups [17].

\subsection{X-ray Diffractometry (XRD)}

Sample phase composition was determined by powder XRD using a D8 propulsive diffractometer (Bruker, Karlsruhe, Germany) with $\mathrm{Cu} \mathrm{K} \alpha$ radiation at $40 \mathrm{kV}$ and $40 \mathrm{~mA}$. XRD spectra were recorded in a $2 \theta$ range of $5-80^{\circ}$, at a step size of $0.02^{\circ}$ and a counting time of $1 \mathrm{~s}$ [18]. 


\subsection{Differential Scanning Calorimetry (DSC)}

DSC (Q200 V24.2 Build 107, New Castle, DE, USA) can be used to determine thermal properties, such as glass transition temperature $\left(T_{g}\right)$, melting temperature $\left(T_{m}\right)$ and crystallization temperature. Herein, the thermal stability of the films was examined using a DSC-50 instrument (Shimadzu) and an empty pan as a reference. The HPe system was heated at an elevated temperature to eliminate previous thermal history, and then cooled at a linear rate before it was heated again. The TA Universal analysis software was used to determine the $T_{g}$ of the HPe system as it was heated from 50 to $350{ }^{\circ} \mathrm{C}$ at a rate of $10^{\circ} \mathrm{C} \cdot \mathrm{min}^{-1}$ under a nitrogen flow $\left(50 \mathrm{~mL} \cdot \mathrm{min}^{-1}\right)[19]$.

\subsection{Density Determination}

The composite film was cut into pieces of the same size $(10 \mathrm{~mm} \times 100 \mathrm{~mm})$, and a thickness gauge with an accuracy of $0.001 \mathrm{~mm}$ (Mitutoyo Absolute, Tester Sangyo Co., Ltd., Tokyo, Japan) was used to measure their thicknesses $(d)$ at one point in the center and four points around the center. The result was expressed as the mean of these five values and presented with an accuracy of $0.001 \mathrm{~mm}$. Mass $(m)$ was determined using an electronic scale with an accuracy of $0.0001 \mathrm{mg}$, and combined with the specimen area $(s)$, was used to calculate film density $(\rho)$ as:

$$
\rho=\frac{m}{s \cdot d^{\prime}}
$$

Density measurements were performed three times for each specimen, and the result was expressed as the mean of these measurements [20].

\subsection{Determination of Water Vapor Permeability (WVP)}

A PERME W3/031 water vapor transmittance tester was used for WVP determination (following ASTM E96 (2016) standard) [21]. The composite film was cut into a disk of $33 \mathrm{~mm}$ radius, and its thickness $(d)$ was measured using a thickness gauge (Mitutoyo Absolute, Tester Sangyo Co., Ltd., Tokyo, Japan) at one point in the center and four points around the center. The result was expressed as the mean of these five values. The samples were put into the water vapor transmittance tester and tested at a temperature of $25^{\circ} \mathrm{C}$ and a relative humidity (RH) of $75 \%$. WVP was calculated as:

$$
W V P=\frac{W V T R}{P\left(R_{1}-R_{2}\right)} \times x,
$$

where $P$ is the saturation vapor pressure of water $(\mathrm{Pa})$ at the test temperature $\left(25^{\circ} \mathrm{C}\right), \mathrm{R}_{1}$ is the $\mathrm{RH}$ in the desiccator, $\mathrm{R}_{2}$ is the $\mathrm{RH}$ in the permeation cell, and $x$ is film thickness $(m)$. Under these conditions, the driving force for water vapor permeation equals $\left[P\left(R_{1}-R_{2}\right)\right]=1753.55 \mathrm{~Pa}$.

\subsection{Determination of Mechanical Properties}

The mechanical properties were determined for bubble- and notch-free samples using a tensile tester (HD B609B-S, Haida International Equipment Co., Ltd., Taichung, China) and appropriate software for data processing (following ASTM (2010) standard) [22]. The samples were cut into $80 \mathrm{~mm} \times 10 \mathrm{~mm}$ pieces and stretched at a rate of $250.00 \mathrm{~mm} \cdot \mathrm{min}^{-1}$ to measure tensile strength, elongation at break and maximum applied force at room temperature. Tests were performed for at least five samples of each formulation [23].

\subsection{Determination of Surface Color}

Surface color was measured using a chromometer (Konica Minolta, CR-400, Tokyo, Japan) and expressed as $L^{*}$ (lightness), $a^{*}$ (redness/greenness) and $b^{*}$ (yellowness/blueness) values. Hunter color values $(L, a$, and $b)$ were determined from the average of five readings at five points in the center of the 
specimen and at four spread-around points for each sample. A white color plate $(L=90.00, a=1.36$, $b=-1.47)$ was employed as the standard background. The total color difference $(\Delta E)$ was calculated as:

$$
\Delta E=\sqrt{(\Delta L)^{2}+(\Delta a)^{2}+(\Delta b)^{2}}
$$

where $\Delta L, \Delta a$ and $\Delta b$ are the differences between the color values of the standard color plate and those of the film samples [24].

\subsection{Determination of Light Transmittance}

The optical properties of composite films were probed by light absorption measurements using a UV-Vis spectrophotometer (Shimadzu UV-1800, Kyoto, Japan) according to the method of Shankar et al. Film strips with dimensions of $10 \mathrm{~mm} \times 60 \mathrm{~mm}$ were placed in the spectrophotometer test cell, and an empty test cell was used as a reference. UV barrier properties and transparency were determined from light transmittances at 280 and 660 nm, respectively. For each film, measurements were performed in triplicate, and the average of three spectra was calculated.

\subsection{Evaluation of Biodegradability}

Biodegradability was determined by measuring the weight loss of the membranes buried under soil [25]. For the biodegradability analysis, the membranes were cut into $6 \mathrm{~cm} \times 1 \mathrm{~cm}$ pieces (further $3 \mathrm{~cm} \times 3 \mathrm{~cm}$ samples were taken for photographing), weighed, tied at one corner with a thread and buried about $15 \mathrm{~cm}$ below the surface of the soil. The buried membranes were removed from the soil every two weeks, washed by deionized water, and dried at $60^{\circ} \mathrm{C}$ until the weight of the films did not change. The weight loss was then calculated using the following equation:

$$
\text { Weight loss }=\frac{W_{i}-W_{d}}{W_{i}},
$$

where $W_{i}=$ initial weight of the specimen and $W_{d}=$ dry weight of the specimen after degradation in soil.

\subsection{Evaluation of Antimicrobial Activity}

Samples from the experimental and control groups were cut into pieces, and $0.5 \mathrm{~g}$ (dry weight) specimens were weighed and placed in Erlenmeyer flasks for high-temperature sterilization. Other Erlenmeyer flasks (not containing samples) were filled with $50 \mathrm{~mL}$ of NA solutions (Take $500 \mathrm{~mL}$ as an example: $1 \mathrm{~mL}$ nutrient broth (Take $100 \mathrm{~mL}$ as an example: $0.3 \mathrm{~g}$ beef extract, $1 \mathrm{~g}$ peptone, $0.5 \mathrm{~g} \mathrm{NaCl}, 100 \mathrm{~mL}$ distilled water) $+499 \mathrm{~mL} \mathrm{0.8 \%} \mathrm{NaCl}$ aq (Take $100 \mathrm{~mL}$ as an example: $0.8 \mathrm{~g} \mathrm{NaCl}$, $100 \mathrm{~mL}$ distilled water)). Escherichia coli and Staphylococcus aureus were transferred via inoculation loops into flasks filled with $150 \mathrm{~mL}$ of nutrient broth and incubated for $24 \mathrm{~h}$ at $37^{\circ} \mathrm{C}$ with stirring. Subsequently, $1 \mathrm{~mL}$ of the incubated broth medium was injected into two Erlenmeyer flasks each, one containing the sample, and the other containing the NA solution. The two flasks were incubated at $37^{\circ} \mathrm{C}$ for $24 \mathrm{~h}$ with stirring, following which a $100 \mu \mathrm{L}$ aliquot of the incubated sample solution was suctioned and uniformly coated on a solid medium. This step was followed by $24 \mathrm{~h}$ incubation in a constant-temperature incubator at $37^{\circ} \mathrm{C}$. The incubated solid medium was then removed and subjected to colony counting [14].

\subsection{Preservation Experiment of Strawberries}

A batch of fresh strawberries (purchased from Dandong, Liaoning) was transported by cold chain. We selecting strawberries of moderate size and similar ripeness and then packed them with different films. The unpacked strawberries were the blank group, and the strawberries with PE films were the control group. The other four groups were wrapped in PVA/CMC, PVA/CMC/ZnO NPs, 
PVA/CMC/ZnO NPs/ $x$ GnP (ZnO NPs: $x \mathrm{GnP}=7: 3$ ) and PVA/CMC/ $x$ GnP (ultrasonication time, 30 min) films. All the samples were kept at $25 \pm 1{ }^{\circ} \mathrm{C}$ and $55 \pm 5 \% \mathrm{RH}$ for 6 days. The preservation indexes were detected every 2 days.

\subsubsection{Weight Loss Ratio}

The weight of strawberries was measured every two days to calculate the weight loss ratio by the following Equation (7):

$$
\text { Weight loss ratio }(\%)=\frac{W_{0}-W_{t}}{W_{0}} \times 100 \%,
$$

where $W_{0}$ is the initial weight of strawberries $(\mathrm{g})$ and $W_{t}$ is the sample weight after storage time $(\mathrm{g})$.

\subsubsection{Firmness}

The firmness of the strawberries was measured by a fruit hardness tester (GY-4, Handpi, Zhejiang, China) using a flat $4 \mathrm{~mm}$ cylindrical probe, which was pressed into three different points in the central zone of each strawberry to a depth of $10 \mathrm{~mm} \mathrm{[26].}$

\subsubsection{Content of Total Soluble Solids (TSS)}

The TSS in the strawberry pulp was determined by an Abbe Refractometer (2WAJ, Shanghai Optical Instrument Co., Ltd., Shanghai, China) and expressed as a percentage.

\subsubsection{Titratable Acidity (TA)}

The TA was determined by the titration of $5 \mathrm{~mL}$ of juice with $0.1 \mathrm{~mol} / \mathrm{L} \mathrm{NaOH}$ using phenolphthalein as the indicator, and the results were expressed as percent citric acid [27].

\subsection{Statistical Analysis}

The final result was expressed as the mean \pm standard deviation. The SPSS 24.0 statistical analysis system was used for analysis of variance (ANOVA) and Duncan's multi-range tests were used for determining significant differences between the groups $(p<0.05)$.

\section{Results and Discussion}

\subsection{Chemical Property-Swelling Property}

Figure 1 shows the dissolution and swelling condition of PVA/CMC, PVA/CMC/ZnO NPs, PVA/CMC/ZnO NPs/xGnP (ZnO NPs: $x$ GnP = 9:1, 7:3, 5:5, 3:7, 1:9), PVA/CMC/xGnP film with 30 min ultrasonication and PVA/CMC/ZnO NPs/ $x \mathrm{GnP}(\mathrm{ZnO} N \mathrm{Ns}: x \mathrm{GnP}=7: 3)$ composite films under different ultrasonication times. During the swelling experiment, all films were wrinkled when they came into contact with water, and the most severe degree of shrinkage was seen with the PVA/CMC film. Is well known that PVA has a high degree of swelling in aqueous solvents [28]. Similarly, CMC also has good hydrophilicity. In addition, we observed that there were holes in the PVA/CMC $/ x \mathrm{GnP}$ film, possibly as a result of the formation of extra pores on the polymer's surface due to the ultrasonication [29]. This could also be because $x \mathrm{GnP}$ is prone to agglomeration under the action of van der Waals forces and $\pi-\pi$ stacking interactions, which leads to the uneven dispersion of the solution and the appearance of pores. 

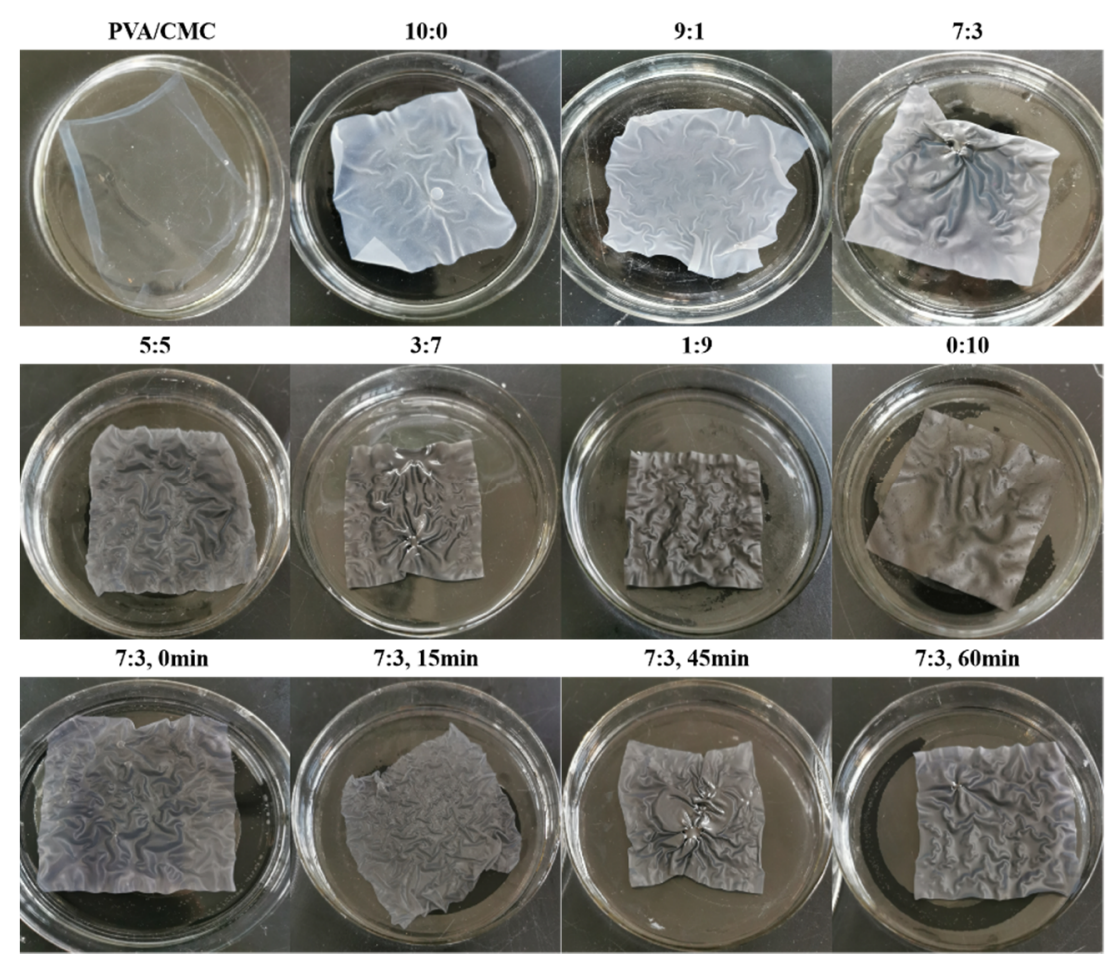

Figure 1. The dissolution and swelling conditions of PVA/CMC, PVA/CMC/ZnO NPs, PVA/CMC/ZnO NPs/xGnP (ZnO NPs:xGnP = 9:1, 7:3, 5:5, 3:7, 1:9), PVA/CMC/ $x \mathrm{GnP}$ film with 30 min ultrasonication and $\mathrm{PVA} / \mathrm{CMC} / \mathrm{ZnO} \mathrm{NPs} / \mathrm{xGnP}(\mathrm{ZnO} \mathrm{NPs}: x \mathrm{GnP}=7: 3)$ composite films under different ultrasonication times.

\subsection{Physical Property}

\subsubsection{Composite Morphology}

Figure 2A shows that the PVA/CMC film had a clear and uniform surface morphology due to good cohesion between its components. This phenomenon corroborated the findings of Fasihi et al. [30], who suggested that the system has a good miscibility ascribed to the H-bond formed between PVA and CMC [19]. The presence of visible spherical particles in the case of films containing ZnO NPs (Figure 2A) was ascribed to particle agglomeration [31]. Further, with the ratio of ZnO NPs and $x \mathrm{GnP}$ changing from 0:10 to 10:0, the number of visible spherical particles increased continuously. However, PVA/CMC/ $x$ GnP films contained aggregates, which was ascribed to the strong attractive interactions between graphene nanosheets preventing their good distribution in the matrix [32]. At the same time, the chemically inert $x \mathrm{GnP}$ is prone to agglomeration under the action of van der Waals forces and $\pi-\pi$ stacking interactions. To obtain a homogenous construction, the nanoparticulate fillers should be separated from each other as much as possible [33]. In contrast, the composite films prepared herein featured a rough texture (Figure 2Ah) in the form of wrinkles and corrugations, which were primarily due to the stacking of graphene sheets [34]. The $x \mathrm{GnP}$-containing films featured flake-shaped structures, the number of which increased with increasing $x \mathrm{GnP}$ content. At a fixed ZnO NPs $+x \mathrm{GnP}$ content, a ZnO NPs: $x$ GnP ratio of 7:3 resulted in the most uniform particle dispersion. Figure $2 \mathrm{Ag}$ shows the presence of $x \mathrm{GnP}$ wrinkles and non-uniform dark flakes. At the same time, the adhesion between the particles and the matrix is quite poor, as revealed by the presence of some voids around the $x \mathrm{GnP}$. The cross-sectional SEM images of the PVA/CMC/ZnO NPs $/ x \mathrm{GnP}$ composite films showed the internal reticular structure, which was more fluffy than that of the untreated PVA/CMC film. The presence of $\mathrm{ZnO}$ NPs and $x \mathrm{GnP}$ in the composite nanofibers was further confirmed by EDS analysis (Figure 2B). 


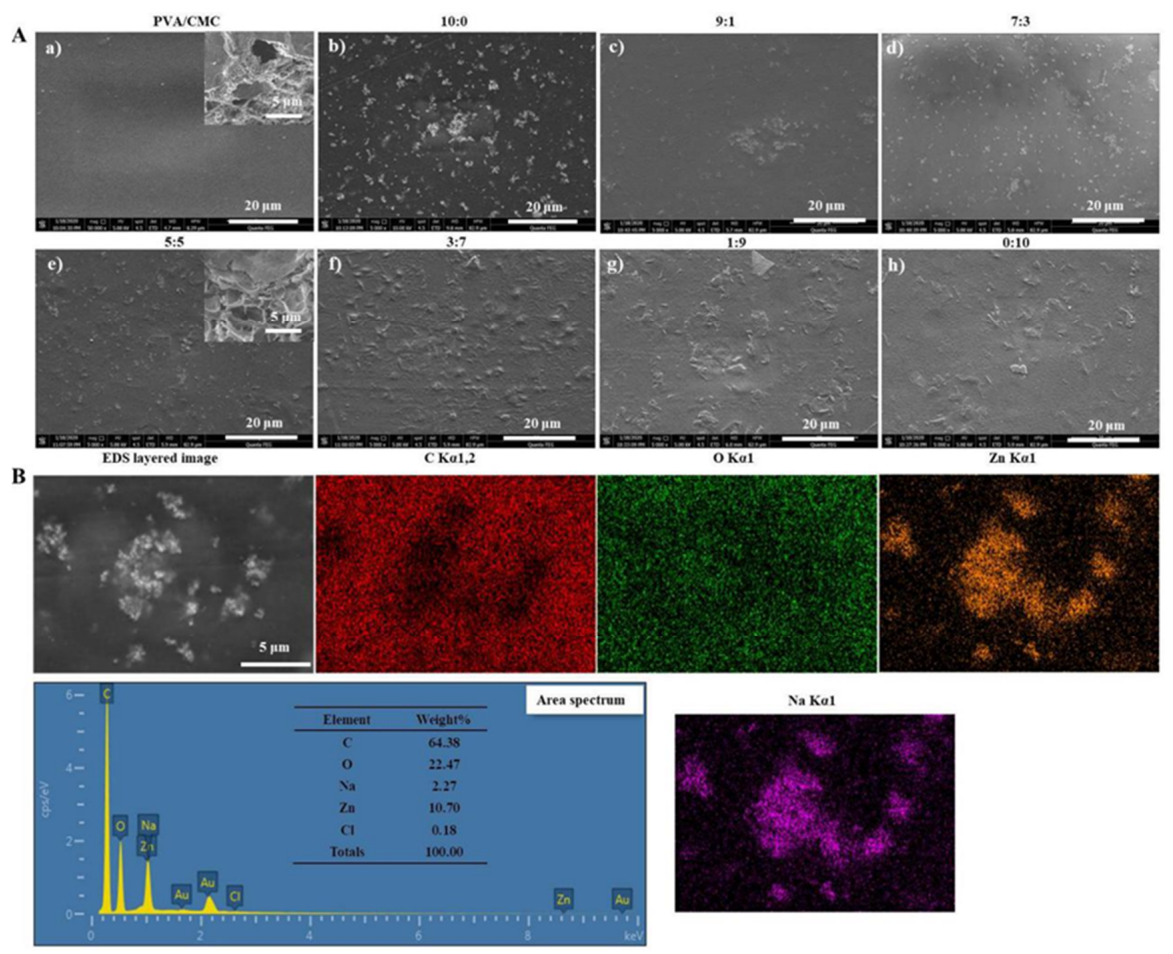

Figure 2. (A) SEM (Scanning Electron Microscope) images of (a) PVA/CMC film, (b-h) and $\mathrm{PVA} / \mathrm{CMC} / \mathrm{ZnO} \mathrm{NPs} / x \mathrm{GnP}$ composite films (with different mass ratios of ZnO NPs-to- $x \mathrm{GnP}$; ultrasonication time, $30 \mathrm{~min}$ ). Inset shows cross-sectional SEM images of the PVA/CMC/ZnO NPs/ $x \mathrm{GnP}$ composite film and PVA/CMC film; (B) EDS images of PVA/CMC/ZnO NPs/ $x \mathrm{GnP}(\mathrm{ZnO}$ NPs: $x \mathrm{GnP}=7: 3$ ) composite film (ultrasonication time, $30 \mathrm{~min}$ ).

\subsubsection{ATR-FTIR Analysis}

Figure 3 shows the ATR-FTIR spectra of $x \mathrm{GnP}, \mathrm{ZnO}$ NPs, PVA/CMC, PVA/CMC/ZnO NPs, $\mathrm{PVA} / \mathrm{CMC} / x \mathrm{GnP}$ and PVA/CMC/ZnO NPs/ $x \mathrm{GnP}$ films. The spectrum of ZnO NPs showed a peak at $1630 \mathrm{~cm}^{-1}$, which is attributed to the $\mathrm{O}-\mathrm{H}$ bonds of water absorbed on the particle surface [35]. $x \mathrm{GnP}$ showed peaks at 3440 and $1630 \mathrm{~cm}^{-1}$ due to the $\mathrm{O}-\mathrm{H}$ stretching vibration of absorbed water and the $C=C$ skeletal vibration of graphene, respectively [19]. The low-frequency scattering to the right of the latter peak (in the region of $1200-1600 \mathrm{~cm}^{-1}$ ) was related to the buffer layer [36]. The spectrum of the PVA/CMC film showed characteristic signals of PVA and CMC, namely the broad peaks at $3500-3100 \mathrm{~cm}^{-1}(\mathrm{O}-\mathrm{H}$ stretching vibrations in PVA and CMC) and narrow peaks at 2920 and $1060 \mathrm{~cm}^{-1}$ (aliphatic C-H and C-O stretches in PVA, respectively) [37]. The peaks at 1060, 1320, 1420 and $1600 \mathrm{~cm}^{-1}$ were characteristic of $\mathrm{CMC}$, and corresponded to $\mathrm{C}-\mathrm{O}-\mathrm{C}$ bending, $-\mathrm{OH}$ bending, $-\mathrm{CH} 2-$ scissoring and asymmetric $-\mathrm{COO}-$ vibrations, respectively. Samsudin et al. [38] reported similar CMC signature bands at 1056, 1334, 1421 and $1581 \mathrm{~cm}^{-1}$, which were carbohydrate signature peaks, confirming the presence of carboxymethyl substituents on the CMC backbone [19]. For the PVA/CMC/ZnO NPs film, the intensities of the above FTIR peaks exceeded those observed for the pure PVA/CMC film. This behavior indicated that some strong inter-component interactions and good dispersions changed the polymer chain arrangement, which was ultimately reflected in the increased peak intensity. The FTIR spectra of PVA/CMC/ZnO NPs films indicated that doping with $\mathrm{ZnO}$ NPs influenced the functional groups of PVA/CMC matrices as a result of the complexation or interaction of these groups with ZnO NPs [5]. The FTIR spectra of PVA/CMC/ZnO NPs films revealed a marginal shift in the positions of the bands corresponding to $\mathrm{OH}$ and $\mathrm{C}=\mathrm{O}$ stretches, which was attributed to the interaction between the ZnO NPs filler and the host PVA/CMC matrix (Figure 3) [39]. By comparing the PVA/CMC/ZnO NPs/ $x \mathrm{GnP}$ films and the PVA/CMC/ZnO NPs films, we can see 
that with the ratio of $\mathrm{ZnO} N P s$ and $x \mathrm{GnP}$ changing from 5:5 to 10:0, the intensity of the -OH peak at $3270 \mathrm{~cm}^{-1}$ increased and shifted to higher wavenumbers, while that of the $\mathrm{COO}-$ and $\mathrm{C}-\mathrm{O}$ peaks increased and broadened, which was attributed to the strong interaction between the above groups and $\mathrm{ZnO}$ NPs [5]. The spectrum of the PVA/CMC/ $x \mathrm{GnP}$ film showed that upon the addition of $x \mathrm{GnP}$ to PVA/CMC, the intensity of other peaks related to PVA/CMC decreased, while the signature band of $x \mathrm{GnP}$ at $3440 \mathrm{~cm}^{-1}$ became red-shifted and broadened, possibly because of the synergetic influence of strain and doping [36]. The characteristic peaks of the PVA/CMC/ZnO NPs $/ x \mathrm{GnP}$ films were similar to (but weaker than) those of the PVA/CMC film, and the $\mathrm{OH}$ stretch of the former at $3380 \mathrm{~cm}^{-1}$ and the asymmetric -COO- stretch at $1600 \mathrm{~cm}^{-1}$ red-shifted to 3260 and $1590 \mathrm{~cm}^{-1}$, respectively, in case of the latter, which indicated a strong interaction between these groups and ZnO NPs or $x \mathrm{GnP}$ [25]. The absence of new peaks suggested that the interactions between $\mathrm{ZnO} N P s$ or $x \mathrm{GnP}$ and the PVA/CMC matrix were purely physical (e.g., hydrogen bonds and van der Waals forces).

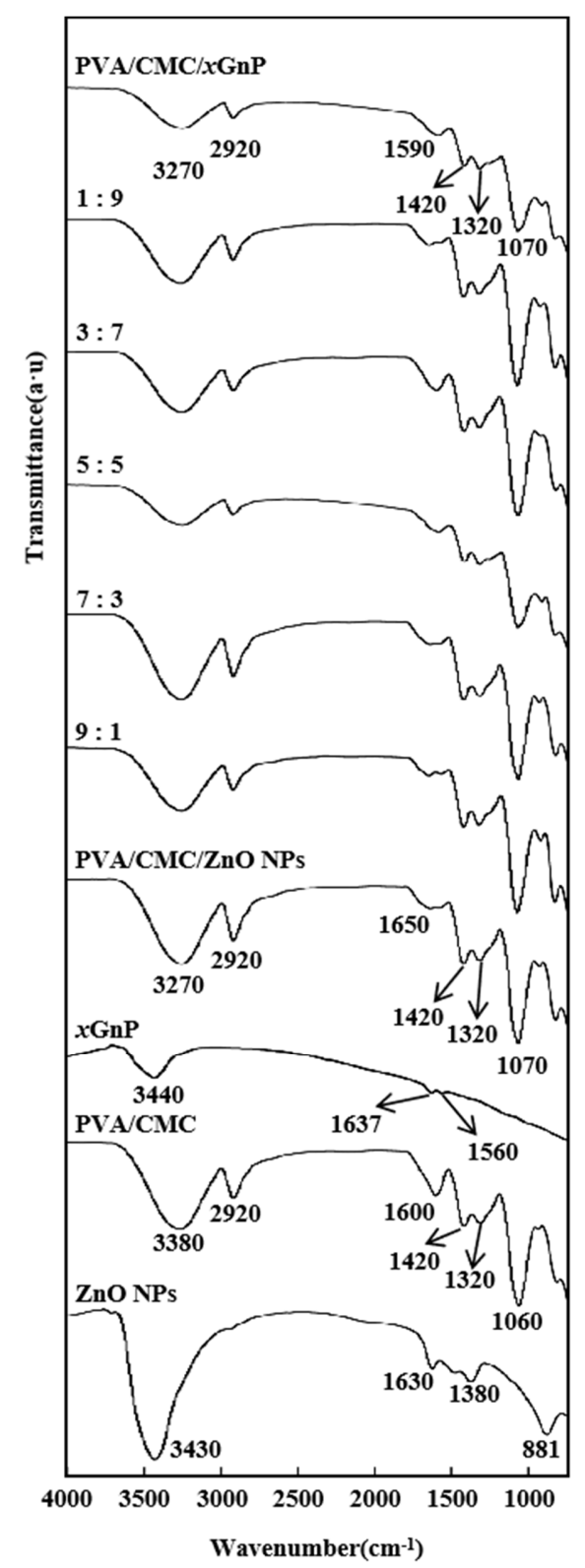

Figure 3. FTIR (Fourier Transform Infrared) spectra of ZnO NPs, PVA/CMC, $x$ GnP, PVA/CMC/ZnO NPs, PVA/CMC/ZnO NPs/ $x$ GnP (ZnO NPs: $x$ GnP $=9: 1,7: 3,5: 5,3: 7,1: 9)$ and PVA/CMC/ $x$ GnP film without ultrasonication. 
Ultrasonication did not change the overall appearance of the FTIR spectra, mainly affecting peak intensity and position [13]. Figure 4 shows the FTIR spectra of PVA/CMC/ZnO NPs/ $x$ GnP composite films prepared using different ultrasonication times. The intensity of the characteristic peak of PVA/CMC decreased after the short ultrasonic treatment, which was ascribed to its promotional effect on the uniform dispersion of $\mathrm{ZnO} \mathrm{NPs}$ and $x \mathrm{GnP}$ in the PVA/CMC matrix and the closer incorporation of the nanofillers into this matrix. However, in the case of the long (60 min) ultrasonication treatment, the peak intensity of PVA/CMC slightly increased, possibly because of the release of the intermolecular hydroxyl groups of PVA/CMC.

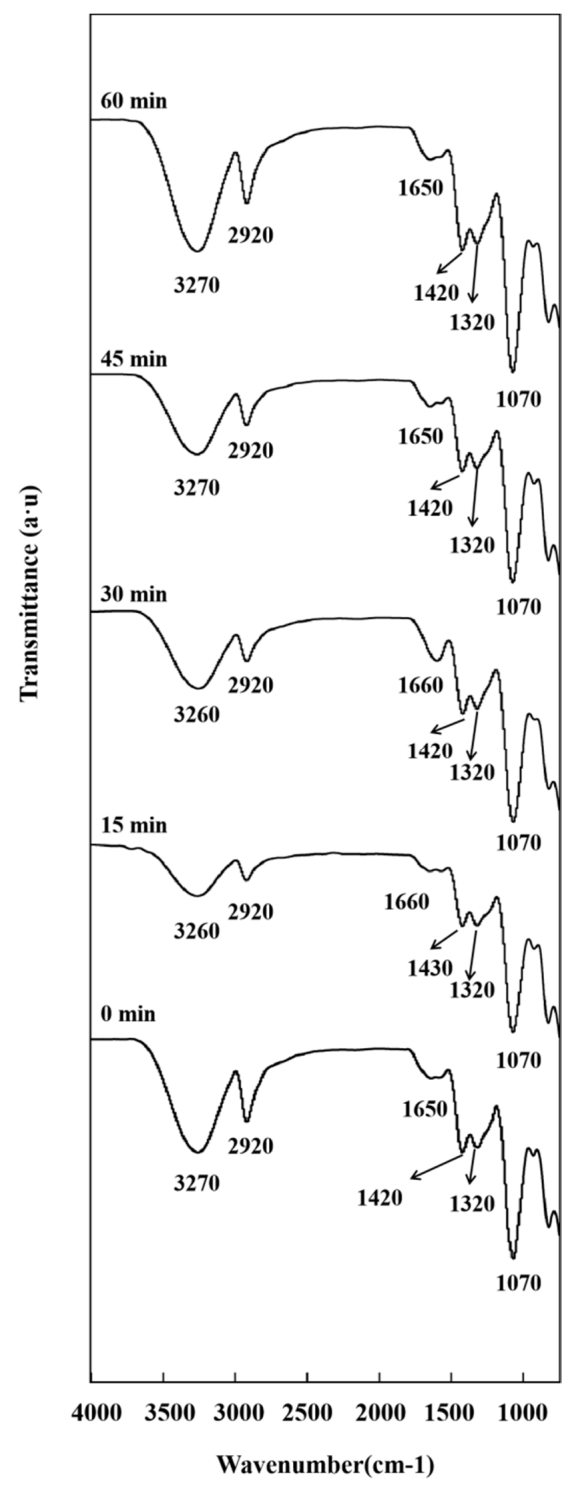

Figure 4. FTIR spectra of PVA/CMC/ZnO NPs/ $x \mathrm{GnP}(\mathrm{ZnO}$ NPs: $x \mathrm{GnP}=5: 5)$ composite films under different ultrasonication times.

\subsubsection{XRD Analysis}

Figure 5 shows the XRD patterns of ZnO NPs, $x \mathrm{GnP}, \mathrm{PVA} / \mathrm{CMC}, \mathrm{PVA} / \mathrm{CMC} / \mathrm{ZnO}$ NPs, PVA/ $\mathrm{CMC} / x \mathrm{GnP}$ and PVA/CMC/ZnO NPs/ $x \mathrm{GnP}$ films. The significant peaks of $\mathrm{ZnO} N \mathrm{Ns}$ at $2 \theta=31.75^{\circ}$, $34.37^{\circ}, 36.26^{\circ}, 47.56^{\circ}, 56.59^{\circ}, 62.85^{\circ}, 67.96^{\circ}, 69.05^{\circ}, 72.55^{\circ}$ and $76.94^{\circ}$ were ascribed to the reflections from the (100), (002), (101), (102), (110), (103), (112), (201), (004) and (202) planes of hexagonal ZnO NPs with a wurtzite structure (space group P63mc, JCPDS No. 36 1451), respectively. No additional 
peaks due to secondary or impurity phases were observed, which confirmed the phase purity of the $\mathrm{ZnO}$ NPs sample. The pattern of $x \mathrm{GnP}$ featured an intense peak at $2 \theta=26.48^{\circ}$, attributed to the stacking of single graphene layers at a distance of $0.34 \mathrm{~nm}$, and other peaks at $2 \theta=43.96^{\circ}$ and $54.62^{\circ}$, corresponding to reflections from the (110) and (102) planes, respectively [40]. In agreement with the findings of Goswami et al. [41] and the known semi-crystalline nature of PVA, as well as the amorphous nature of CMC, the XRD pattern of PVA/CMC displayed broad peaks at $2 \theta=19.46^{\circ}$ and $40.50^{\circ}$, which indicated the existence of a typical semi-crystalline structure and suggested that PVA strongly interacted with CMC [42]. The pattern of the PVA/CMC/ZnO NPs film showed the characteristic peaks of $\mathrm{ZnO} N \mathrm{Ns}$ at $2 \theta=31.75^{\circ}, 34.37^{\circ}, 36.26^{\circ}, 47.56^{\circ}, 56.59^{\circ}, 62.85^{\circ}, 67.96^{\circ}$ and $69.05^{\circ}$, as well as those of the PVA/CMC film at $2 \theta=19.46^{\circ}$ and $40.50^{\circ}$. Thus, the introduction of ZnO NPs did not change the crystal structure of the PVA/CMC matrix, and the $\mathrm{ZnO}$ nanostructures were well crystallized in the polymer matrix as no new peaks or peak shifts were observed. The patterns of the PVA $/ \mathrm{CMC} / x \mathrm{GnP}$ and PVA/CMC/ZnO NPs $/ x \mathrm{GnP}$ films showed the peak of semi-crystalline PVA at $2 \theta=19.46^{\circ}$, and the characteristic peaks of $x \mathrm{GnP}$ at $2 \theta=26.48^{\circ}$ and $54.62^{\circ}$, indicating that $x \mathrm{GnP}$ sheets could not be dispersed or completely separated, with some sheets existing in a stacked form [43]. Compared with those of the PVA/CMC/ $x \mathrm{GnP}$ film, the peaks of the PVA/CMC/ZnO NPs $/ x \mathrm{GnP}$ film at $2 \theta=26.48^{\circ}$ and $54.62^{\circ}$ were significantly weakened, i.e., the intensity of these peaks increased with the increasing loading of $x \mathrm{GnP}$, possibly because of the concomitant increase in the number of stacked $x \mathrm{GnP}$ layers. The pattern of the PVA/CMC/ZnO NPs $/ x \mathrm{GnP}$ film also featured the characteristic peaks of $\mathrm{ZnO} N P s$ at $2 \theta=31.75^{\circ}, 34.37^{\circ}$ and $36.26^{\circ}$, and the decreased intensity of these peaks (compared with that observed for $\mathrm{ZnO}$ NPs) implied that the ZnO NPs were incorporated into PVA/CMC [5].

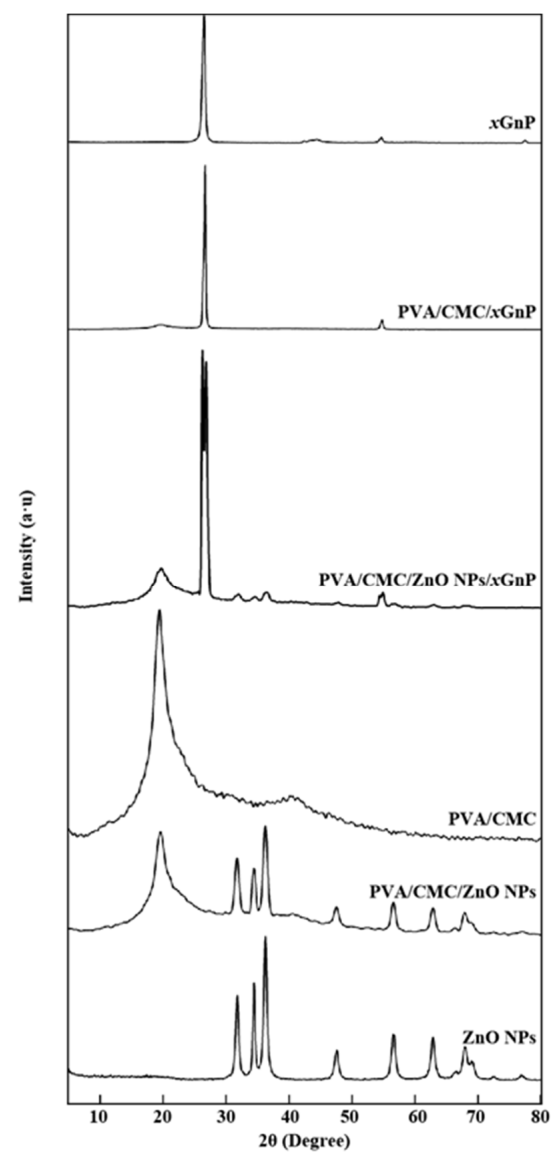

Figure 5. XRD (X-Ray Diffractometry) patterns of ZnO NPs, $x \mathrm{GnP}$, the pure PVA/CMC film, $\mathrm{PVA} / \mathrm{CMC} / \mathrm{ZnO} \mathrm{NPs}, \mathrm{PVA} / \mathrm{CMC} / x \mathrm{GnP}$, and the PVA/CMC/ZnO NPs/ $x \mathrm{GnP}(\mathrm{ZnO} \mathrm{NPs}: x \mathrm{GnP}=7: 3)$ composite film (ultrasonication time, $30 \mathrm{~min}$ ). 


\subsubsection{DSC Analysis}

The DSC curve of the PVA/CMC film exhibited three endothermic peaks at 92.52, 222.03 and $313.69{ }^{\circ} \mathrm{C}$, as well as a small exothermic peak at $289.65{ }^{\circ} \mathrm{C}$ (Figure 6 and Table 1). The peaks at 92.52 and $222.03{ }^{\circ} \mathrm{C}$ indicated the presence of two phases, and suggested that the two polymers were partially miscible and engaged in some sort of interaction with each other [41]. Had this not been the case, the transitions of each polymer in the PVA/CMC blend would occur at similar vitreous transition temperatures [41]. The peak at $289.65{ }^{\circ} \mathrm{C}$ is considered to be the crystalline transition. The addition of $\mathrm{ZnO} N P s$ and $x \mathrm{GnP}$ increased the $T_{g}$ of the composite film, with values of 115.48 , 119.92 and $99.07^{\circ} \mathrm{C}$ observed for PVA/CMC/ZnO NPs, PVA/CMC/ $x \mathrm{GnP}$ and PVA/CMC/ZnO NPs $/ x \mathrm{GnP}$, respectively. This behavior was ascribed to the good compatibility between $\mathrm{ZnO} \mathrm{NPs} / x \mathrm{GnP}$ and the $\mathrm{PVA} / \mathrm{CMC}$ polymer matrix, as well as to the strong interfacial interactions between these components, which reduced the mobility of chain segments and allowed chain segment motion to occur only at higher temperatures [44].

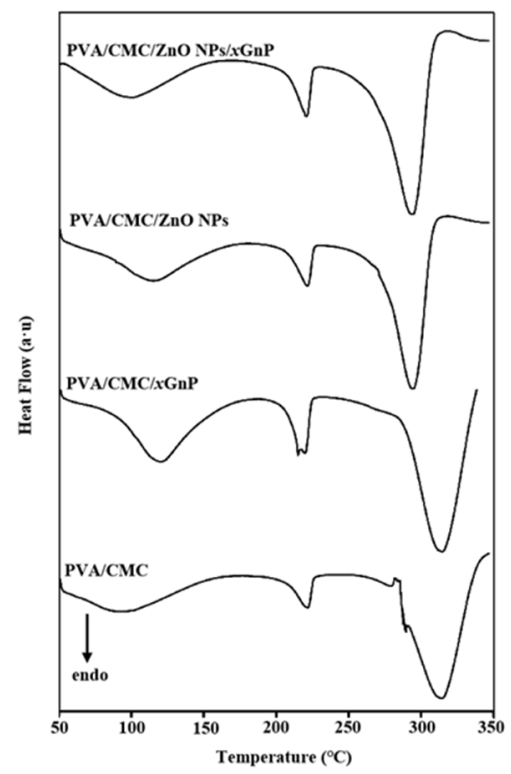

Figure 6. DSC (Differential Scanning Calorimetry) thermograms of pure PVA/CMC, PVA/CMC/ $x \mathrm{GnP}$, $\mathrm{PVA} / \mathrm{CMC} / \mathrm{ZnO} \mathrm{NPs}$ and PVA/CMC/ZnO NPs/ $x \mathrm{GnP}$ (ZnO NPs: $x \mathrm{GnP}=7: 3$ ) composite films without ultrasonication.

Table 1. The values of $T_{g}$ and $T_{m}$ of pure PVA/CMC, PVA/CMC/xGnP, PVA/CMC/ZnO NPs and $\mathrm{PVA} / \mathrm{CMC} / \mathrm{ZnO} \mathrm{NPs} / x \mathrm{GnP}$ (ZnO NPs: $x \mathrm{GnP}=7: 3$ ) composite films without ultrasonication.

\begin{tabular}{ccccc}
\hline Sample & $\boldsymbol{T}_{\boldsymbol{g}}\left({ }^{\circ} \mathbf{C}\right)$ & $\boldsymbol{T}_{\boldsymbol{c}}\left({ }^{\circ} \mathrm{C}\right)$ & $\boldsymbol{T}_{\boldsymbol{m}}\left({ }^{\circ} \mathbf{C}\right)$ & $\boldsymbol{X}_{\boldsymbol{c}}\left({ }^{\circ} \mathbf{C}\right)$ \\
\hline PVA/CMC & 92.52 & 226.49 & 221.80 & 45.52 \\
PVA/CMC/ZnO NPs & 115.48 & 227.48 & 221.92 & 49.33 \\
PVA/CMC/ $x$ GnP & 119.92 & 226.21 & 220.24 & 46.94 \\
PVA/CMC/ZnO NPs/xGnP & 99.07 & 226.68 & 221.21 & 53.20 \\
\hline
\end{tabular}

$T_{g}$ : transition temperature of the plate glass, $T_{c}:$ critical temperature, $T_{m}:$ melting temperature, $X_{c}$ : capacitive reactance.

Melt characteristics are important parameters for studying composite thermal stability, as they can reflect intermolecular bonding strength in polymer blends [45]. The melting process can be regarded largely as unaffected by $\mathrm{ZnO}$ or graphene. Compared to those of the PVA/CMC film $\left(T_{m}=221.80{ }^{\circ} \mathrm{C}\right)$, the Tm values of the PVA/CMC/ $x \mathrm{GnP}$ films were slightly lower $\left(220.24^{\circ} \mathrm{C}\right)$, possibly because the good dispersion of nanofillers in the PVA/CMC matrix improved component compatibility and allowed the formation of exfoliated and/or embedded composite films [32]. The $T_{g}$ value of the pure PVA/CMC 
film was $92.52{ }^{\circ} \mathrm{C}$, which is in line with that reported in the literature [46]. Compared to those of the PVA/CMC films, the $T_{g}$ values of the composite films with added $\mathrm{ZnO}$ NPs or $x \mathrm{GnP}$ were higher. For the rest of the composites, the nanoparticles can induce an increase in the $T_{g}$. The thermal stability of nanocomposites depends on the state of the filler dispersion, interfacial interactions between the filler and the matrix, filler particle size, and polymer molecular weight and crystallinity [47]. The enhanced crystallinity of the composite film observed herein was ascribed to the nucleation of $x \mathrm{GnP}$ and $\mathrm{ZnO}$ NPs. Figure 5 reveals that a strong characteristic peak at $26.48^{\circ}$ was observed for $x \mathrm{GnP}$, indicating that $x \mathrm{GnP}$ itself was highly ordered and thus implying that a large number of polymer chains could possibly be effectively aligned along the crystal nuclei $(x \mathrm{GnP})$, in order to induce crystallization and improve crystallinity [48]. This suggestion is in line with the reported ability of reinforcing substances to serve as nucleating agents and thus provide a surface for the heterogeneous crystallization of polymers [47].

\subsubsection{WVP}

Figure 7 shows that with the decreasing ZnO NPs: $x \mathrm{GnP}$ ratio, the WVP of composite films first decreased and then increased, lying in the range of 3.92-9.88 $\times 10^{-13} \mathrm{~g} \cdot \mathrm{Pa}^{-1} \cdot \mathrm{s}^{-1} \cdot \mathrm{cm}^{-1}$. The reduction in WVP upon the introduction of $\mathrm{ZnO}$ NPs, reported for many bionanocomposites, is mainly ascribed to the hydrophobic nature of this nanofiller and the concomitant generation of a tortuous pathway for water vapor molecules to pass through [24]. The minimum WVP of $5.29 \pm 0.13 \times 10^{-13} \mathrm{~g} \cdot \mathrm{Pa}^{-1} \cdot \mathrm{s}^{-1} \mathrm{~cm}^{-1}$ (observed at a ZnO NPs: $x \mathrm{GnP}$ ratio of 5:5) was 35.55\% lower than that of the pure PVA/CMC film, which was attributed to the change in the original molecular chain structure of PVA/CMC and the interfacial interaction between ZnO NPs NPs and $x \mathrm{GnP}$ due to the binding of ZnO NPs NPs with $x \mathrm{GnP}$. In contrast to that of ZnO NPs, the graphene-PVA/CMC binding force was believed to be weak, resulting in increased WVP because of the formation of numerous pores on the surface of the composite film upon $x \mathrm{GnP}$ addition. In a word, both $\mathrm{ZnO}$ NPs and $x \mathrm{GnP}$ had a profound impact on WVP, which increased as a result of crystallinity reduction and decreased because of the formation of a tortuous path due to the nucleation between $\mathrm{ZnO}$ NPs and $x \mathrm{GnP}$, in line with DSC results (Figure 6).

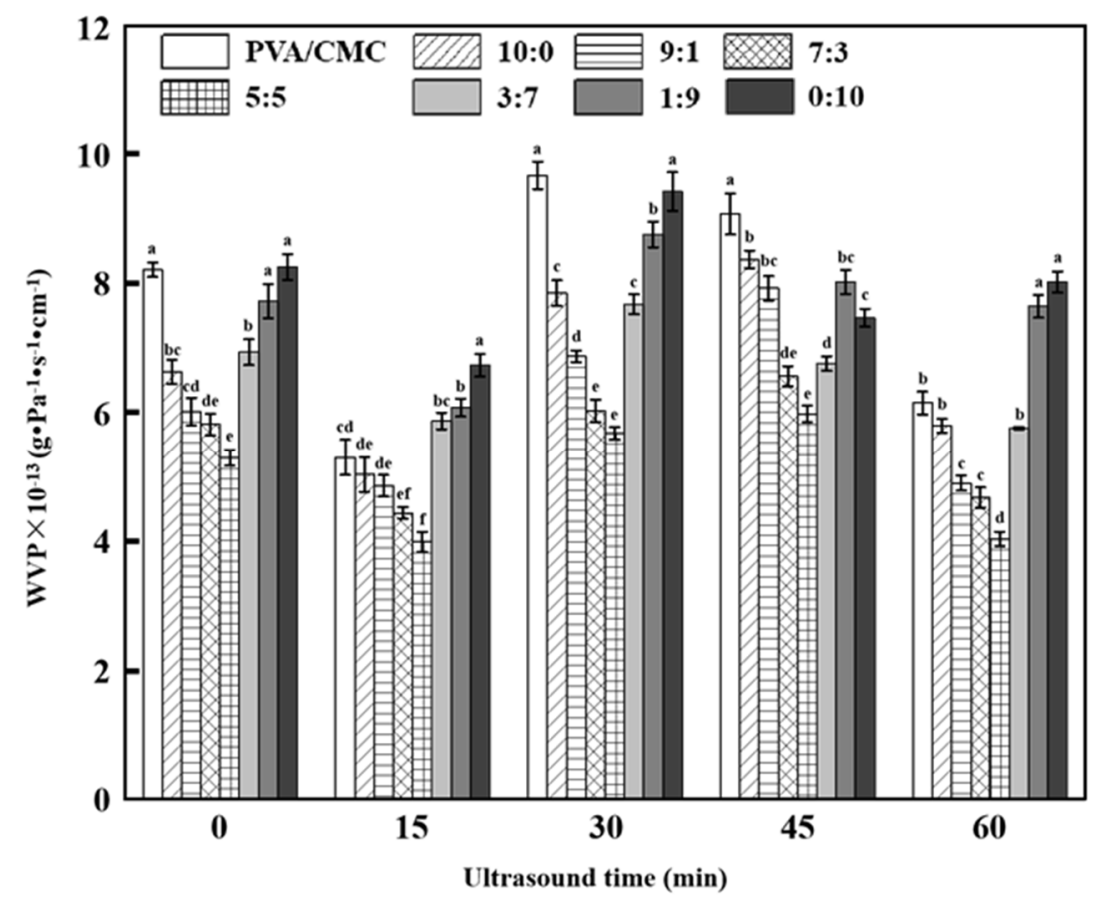

Figure 7. WVP (Determination of Water Vapor Permeability) of pure PVA/CMC and PVA/CMC/ZnO $\mathrm{NPs} / x \mathrm{GnP}$ composite films under different ultrasonication times. $\left({ }^{*} p<0.05, n=8\right)$. 
With increasing ultrasonication time, the WVP of composite films first increased and then decreased. The WVP increase was ascribed to the thermal effect of ultrasonication, which enhanced molecular movement and exposed the hydrophilic groups of PVA molecules. The highest WVP of the PVA/CMC film $\left(9.67 \pm 0.21 \times 10^{-13} \mathrm{~g} \cdot \mathrm{Pa}^{-1} \cdot \mathrm{s}^{-1} \cdot \mathrm{cm}^{-1}\right)$ was obtained at an ultrasonication time of $30 \mathrm{~min}$. The strong thermal, mechanical, super-mixing and cavitation effects of ultrasound treatment can make the particles oscillate and collide at high speed to break the hydrogen and hydrophobic bonds in the medium, thus facilitating the formation of nonpolar bonds and, hence, the process of film densification [12]. Moreover, ultrasonication further improves material solubility, makes the film form a more compact network structure, and induces stirring that promotes the uniform macro-scale distribution of particles in solution. The cavitation effect can further homogenize particles on the micro scale, facilitate the separation and uniform distribution of graphene and ZnO NPs in the matrix, and increase the compactness of the composite film to reduce WVP [14]. Notably, the PVA/CMC film subjected to 60 min ultrasonication did not feature the lowest WVP, possibly because this time was insufficient for polymer destruction.

\subsubsection{Mechanical Properties}

Figure $8 \mathrm{a}$ shows that the addition of $\mathrm{ZnO}$ NPs and $x \mathrm{GnP}$ significantly changed the elongation at break $(p<0.05)$, which first increased and then decreased with decreasing ZnO NPs: $x \mathrm{GnP}$ ratio. At a ZnO NPs: $x \mathrm{GnP}$ ratio of 10:0, the composite film exhibited a strain of $164.56 \pm 6.64 \%$, which was $22.77 \%$ higher than that of the pure PVA/CMC film $(134.04 \pm 7.43 \%)$. This behavior was ascribed to the stiffness of hter ZnO NPs and their favorable hydrogen bonding interactions with PVA [49]. The lowest elongation at break was observed at a ZnO NPs: $x \mathrm{GnP}$ ratio of 5:5, possibly because the fillers themselves and especially the filler-matrix interface are stressed, and may lose structural integrity, which may manifest as the formation of holes in the matrix that create an initial fracture [48]. The increase in elongation at break initially observed with increasing $x \mathrm{GnP}$ dosage was attributed to the good dispersion of $x \mathrm{GnP}$ achieved during compounding [50]. This behavior was ascribed to the strong adsorption of graphene, which may limit the movement of PVA/CMC molecular chains to increase tensile strength. Moreover, graphene can increase compatibility between ZnO NPs and PVA/CMC and provide the effect of particle reinforcement [51]. Finally, the beneficial effect of $x \mathrm{GnP}$ can also be ascribed to the high mechanical strength of graphene sheets [52]. As the graphene loading increased from 0 to 10, the elongation at break increased from $134.04 \pm 7.43 \%$ to $175.61 \pm 7.38 \%$, decreasing at higher loadings. This behavior was rationalized as follows. An increase in graphene loading induces the internal stratification of the composite, and the accumulation of graphene sheets leads to stress concentration and, hence, to premature failure and reduced elongation at break.
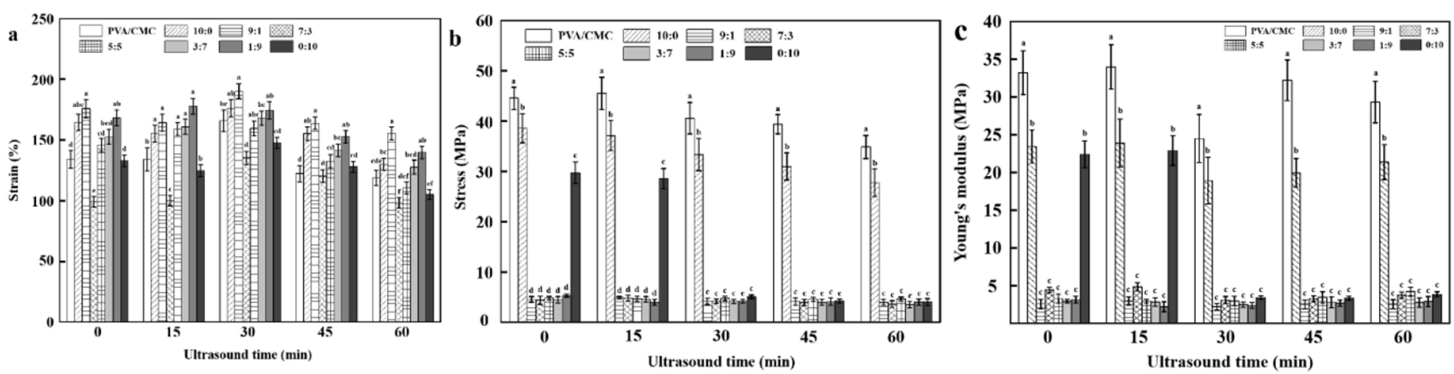

Figure 8. Strain (a), Stress (b) and Young's modulus (c) of pure PVA/CMC film and PVA/CMC/ZnO $\mathrm{NPs} / x \mathrm{GnP}$ composite films under different ultrasonication times. $\left({ }^{*} p<0.05, n=8\right)$.

The tensile strength of a material reflects its resistance to the breaking process when a constant load is applied on the material. Another significant mechanical property is the Young's modulus, also called the elastic modulus, which is a property of linear elastic solid materials. This property describes the relationship between the stress and the strain of a material [41]. Figure $8 \mathrm{c}$ shows that 
the addition of $\mathrm{ZnO} N P$ s and $x \mathrm{GnP}$ significantly affected the Young's modulus. This combines with Figure $8 b$, showing that the variation trend in the tensile strength of the composite film was basically the same as the Young's modulus $(p<0.05)$. Pure PVA/CMC films featured a maximum tensile strength of $45.50 \pm 3.18 \mathrm{MPa}$ and a maximum Young's modulus of $33.95 \pm 2.93 \mathrm{MPa}$, which was hardly affected by the incorporation of only ZnO NPs or graphene. This finding was ascribed to the poor compatibility between $\mathrm{ZnO}$ NPs or $x \mathrm{GnP}$ and PVC/CMC, which resulted in weak interfacial adhesion between the two phases, and hence in the easy initiation and propagation of cracking at the corresponding interface [51]. However, this impact was small. At a ZnO NPs: $x \mathrm{GnP}$ ratio of 9:1, the Young's modulus of the composite film sharply decreased to $2.61 \pm 0.62 \mathrm{MPa}$, which was $92.14 \%$ lower than that of the pure PVA/CMC film $(33.21 \pm 2.90 \mathrm{MPa})$, i.e., the addition of $x \mathrm{GnP}$ reduced the plasticity of the material. This behavior was in line with the results of Ranjan et al. [53], and was ascribed to the antagonism between crack bridging, crack arrest and strong interface formation.

With increasing the ultrasonication time, the elongation at break of the composite films first increased and then decreased, which was explained as follows. The intense vibration induced by ultrasonication reduced the matrix porosity and the matrix-fiber clearance to increase the tensile strength and afford more compact structures, as well as improving the mechanical properties and allowing good film formation, as reported previously $[54,55]$. Moreover, prolonged ultrasonication led to the formation and exposure of more reaction centers, accelerating the rate of chemical reactions and allowing the faster recombination of macromolecules in order to increase tensile strength. The concomitant formation of a more closely bound network structure resulted in increased elongation at break. The mechanical properties of pure PVA/CMC films improved with increasing ultrasonication time, and were optimal (2.26\% higher elongation at break than that of the pure PVA/CMC film) in the case of the $15 \mathrm{~min}$ ultrasonication. However, the elongation at break decreased for longer treatment times, as the excessive polymer damage inflicted under these conditions resulted in the formation of extra pores on the polymer surface, and hence reduced density [54]. At an ultrasonication time of $60 \mathrm{~min}$, the elongation at break was $21.71 \%$ lower than that observed for the non-ultrasonicated film.

\subsubsection{Surface Color}

Figure 9 shows the pictures of the pure PVA/CMC film and the PVA/CMC/ZnO NPs/ $x \mathrm{GnP}$ composite film (ultrasonication time, $30 \mathrm{~min}$ ), corresponding to Table A1. Table A1 lists the colors and transmittances of the PVA/CMC and PVA/CMC/ZnO NPs/ $x \mathrm{GnP}$ films, revealing that the PVA/CMC film was colorless and transparent, while the PVA/CMC/ZnO NPs film was white and featured a higher $L$ value than the former film $(p>0.05)$, which was ascribed to the whitening effect of $\mathrm{ZnO}$ $\mathrm{NPs}$ [24]. The incorporation of $x \mathrm{GnP}$ into the PVA/CMC/ZnO NPs $/ x \mathrm{GnP}$ films resulted in darker colors, significantly decreasing $L$ and increasing $a$ and $b(p<0.05)$, and the extent of these changes was found to be elevated with increasing $x \mathrm{GnP}$ content. At the lowest $x \mathrm{GnP}$ content, the $L$ value (48.70 \pm 1.12$)$ was $46.35 \%$ lower than that of the PVA/CMC film $(90.78 \pm 0.26)$, and the $\Delta E$ value was significantly higher $(42.35 \pm 0.95)$ than that of the PVA/CMC film $(1.13 \pm 0.04)$, i.e., $x \mathrm{GnP}$ had a significant effect on film color. This result was in line with the findings of Zhang et al. [25], who demonstrated that the incorporation of graphene oxide into PVA-based composite films resulted in their darkening $(p>0.05)$.

Ultrasonic treatment also influenced film color and transmittance. Table A1 shows that ultrasonication did not significantly change the $L^{*}, a^{*}$ or $b^{*}$ values of PVA/CMC, PVA/CMC/ZnO NPs and PVA/CMC/ $x \mathrm{GnP}$ films ( $p>0.05)$, but significantly affected the $L^{*}$ value of some PVA/CMC/ZnO $\mathrm{NPs} / x \mathrm{GnP}$ films. This behavior was explained by the beneficial effects of heating and cavitation, generated by ultrasonic treatment, on the dispersion of $x \mathrm{GnP}$ in water at low $x \mathrm{GnP}$ content and high $\mathrm{ZnO}$ NPs content [56]. Thus, under these conditions, $x \mathrm{GnP}$ was uniformly distributed in the composite film (because of their high content, ZnO NPs easily agglomerated in the PVA/CMC matrix) to result in a dark color. In addition, proper ultrasonication $(15,30$ and $45 \mathrm{~min})$ could reduce the transmittance of the composite film $(p>0.05)$. However, when the ultrasonication time increased to $60 \mathrm{~min}$, the transmittance of the composite film increased $(p<0.05)$, possibly because overly long 
ultrasonic treatment reduced the viscosity of the film-forming solution and polymer molecular weight by inflicting damage on the network structure of PVA/CMC, thus increasing the amount of holes on the composite film's surface $[57,58]$.

PVA/CMC

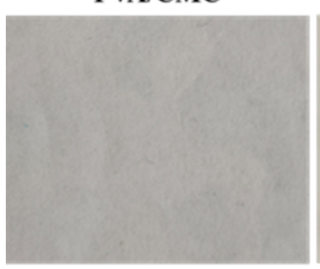

$5: 5$

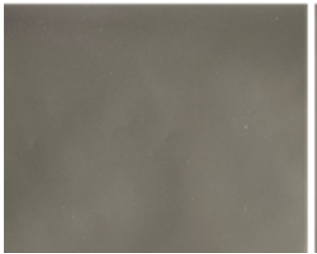

$10: 0$

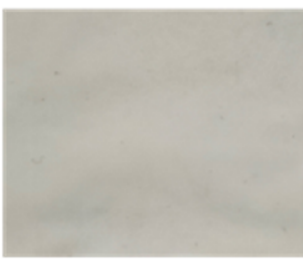

$3: 7$

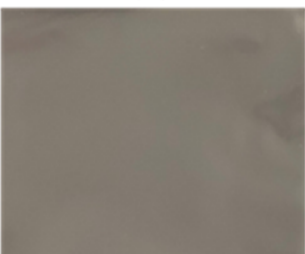

9:1

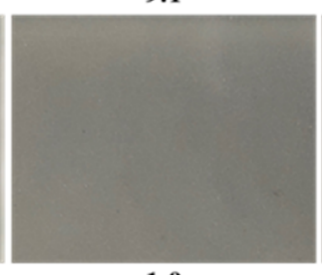

$1: 9$

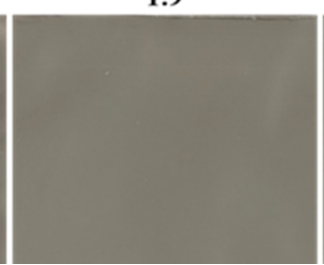

$7: 3$

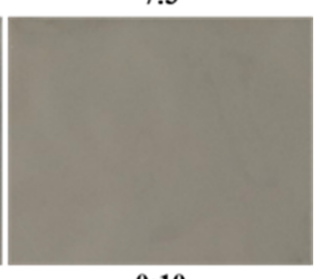

0:10

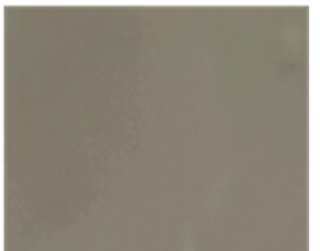

Figure 9. Pictures of the pure PVA/CMC film and the PVA/CMC/ZnO NPs $/ x$ GnP composite film (ultrasonication time, $30 \mathrm{~min}$ ).

\subsubsection{Antimicrobial Activity}

Figure 10a shows that whereas PVA/CMC films did not show any antimicrobial activity, films doped with $\mathrm{ZnO}$ NPs and $x \mathrm{GnP}$ had good antibacterial activity, which was positively correlated with $\mathrm{ZnO}$ NPs content. The highest antibacterial activity was observed for the PVA/CMC/ZnO NPs film, which inhibited the proliferation of $E$. coli and S. aureus by $94.53 \pm 1.85 \%$ and $96.42 \pm 2.32 \%$, respectively. Composite films containing ZnO NPs had a stronger inhibitory effect on S. aureus than on E. coli, which was related to the mechanism of ZnO NPs action and the cell structure of the two bacteria. According to Espiti et al. [8], Gram-negative bacteria have an additional outer film compared with Gram-positive bacteria, and the negative charge of the film of S. aureus is smaller than that of E. coli. Hence, $S$. aureus more strongly interacts with the negatively charged reactive oxygen species generated by $\mathrm{ZnO}$ NPs (which, however, is only one mechanism of its antibacterial action).

With increasing $x \mathrm{GnP}$ content, antibacterial activity weakened, and the inhibition efficiencies of the PVA/CMC/ $x$ GnP film for $E$. coli and S. aureus decreased to $48.30 \pm 2.31 \%$ and $50.02 \pm 2.74 \%$, respectively, which values were $48.91 \%$ and $48.12 \%$ lower than the respective values of the PVA/CMC/ZnO NPs film. This behavior was ascribed to the fact that $x \mathrm{GnP}$ has a weaker antibacterial effect than $\mathrm{ZnO}$ NPs [50]. At present, the antibacterial activity of $x \mathrm{GnP}$ is mainly rationalized as follows: (i) The sharp edges of $x \mathrm{GnP}$ can physically damage bacterial cell films, inducing causing the leakage of intracellular materials and, thus, cell death; (ii) $x \mathrm{GnP}$ internalized by bacterial endocytosis and phagocytosis can promote the generation of reactive oxygen species in bacterial cells, thereby inactivating bacteria; (iii) Given that the bacterial cell surface is negatively charged, $x \mathrm{GnP}$ can act as a "bridge" for charge transfer to destroy film integrity and cause bacterial death; (iv) As $x \mathrm{GnP}$ has a flexible plane and a strong adsorption capacity, it can be adsorbed by bacterial cells to inhibit their proliferation and even induce cell death [59]. However, studies on the antibacterial activity of $x \mathrm{GnP}$ are few in number. Girdthep et al. [48] reported that the good interaction between E. coli and hydrophobic $x \mathrm{GnP}$ favors the attachment of these bacterial cells to $x \mathrm{GnP}$, which causes cell lysis. Akhavan et al. [60] also found that upon contact with bacterial cells, $x \mathrm{GnP}$ can severely damage their films and inactivate these cells. 

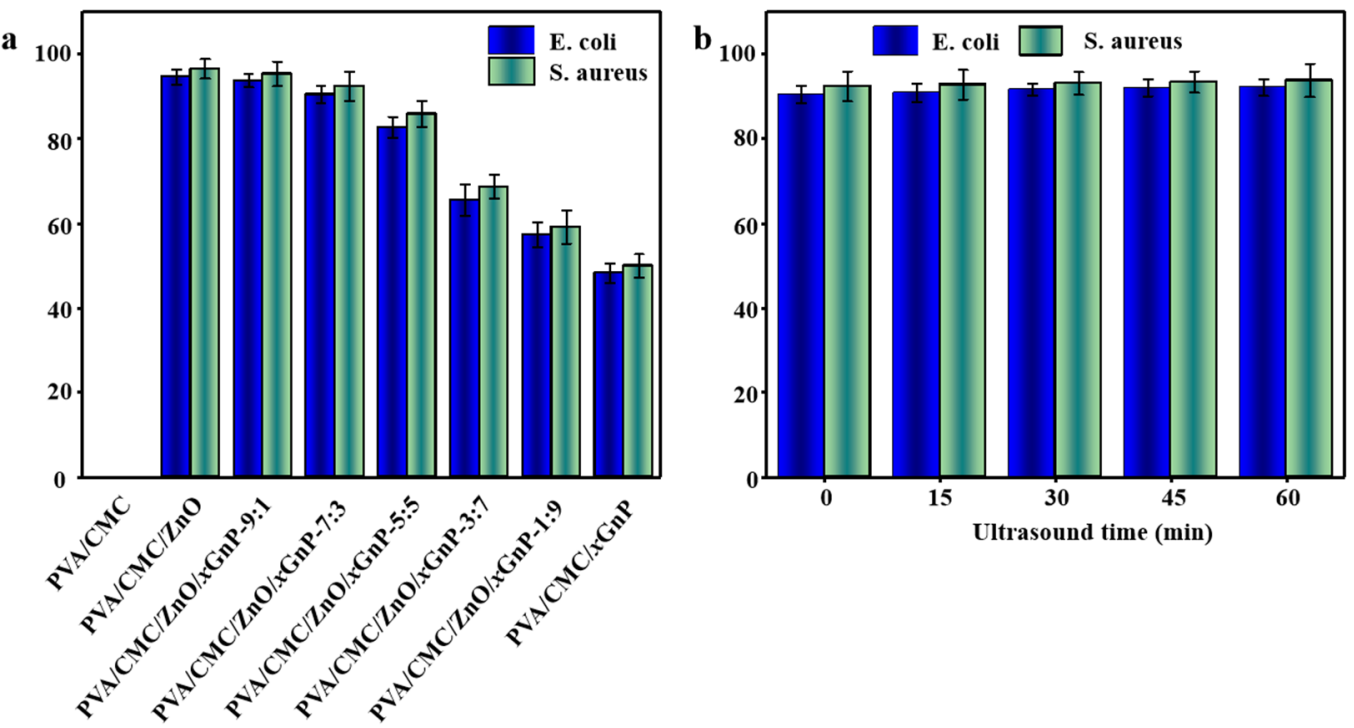

Figure 10. (a) The antibacterial activities of the PVA/CMC and PVA/CMC/ZnO NPs/ $x \mathrm{GnP}$ composite films against Gram-positive (S. aureus) and Gram-negative (E. coli) foodborne pathogenic bacteria; (b) The antibacterial activities of the PVA/CMC/ZnO NPs $/ x \mathrm{GnP}$ composite film with a ZnO NPs-to- $x \mathrm{GnP}$ mass ratio of 7: 3 under different ultrasound times.

With increasing ultrasonication time, the antibacterial activity of composite films increased, but the difference between treatment times was not significant $(p>0.05)$ (Figure 10b). After $60 \mathrm{~min}$ ultrasonication, the E. coli and S. aureus inhibition efficiencies increased to $92.04 \pm 2.00 \%$ and $93.70 \pm 3.91 \%$, respectively, which values were $1.83 \%$ and $1.49 \%$ higher than the values observed without ultrasonication, respectively, in agreement with the results previously reported by Zhang et al. [25]. This behavior was ascribed to nanofiller dispersion into smaller aggregates upon ultrasonication, which increased the specific surface area of $\mathrm{ZnO}$ NPs and $x \mathrm{GnP}$, increasing the probability of contact between the nanofiller and microbial cells, thereby enhancing the antibacterial effect. In addition, the release of kinetic and thermal energy upon ultrasonication facilitated the release of ZnO NPs and $x \mathrm{GnP}$ in the polymer, improving antibacterial activity [14]. Therefore, the use of ultrasonic treatment to improve the antibacterial properties of composite films is worthy of further research.

\subsection{Safety Issues}

We consulted a series of related documents in the early stages of the experiment and found that the migration number of nanomaterials was within the scope of safety standards. For example, Heydari-Majd et al. [61] studied the content of $\mathrm{Zn}^{2+}$ ions in fish fillets wrapped in PLA/ZnO composite membranes, and found that the migration quantities of $\mathrm{Zn}^{2+}$ ions from the nanocomposite membrane to the fillet measured up to $1.551 \pm 0.160 \mathrm{mg} / 100 \mathrm{~g}$ sample, which was still far below the migration limit of $40 \mathrm{mg} /$ day for zinc daily consumption as defined by the National Institute of Health for food contact materials. Panea et al. [62] analyzed the migration of $\mathrm{ZnO}$ and $\mathrm{Ag}$ particles in the aqueous food simulant by inductively coupled plasma mass spectrometry (ICP-MS), and found that the migration of nanoparticles in the simulant was very low, the migration of $\mathrm{Zn}^{2+}$ in the control package was below the detection limit $(<0.005 \mathrm{mg} / \mathrm{kg})$, and in the packaging of the added nanoparticles, only $2.44 \pm 0.37 \mathrm{mg} / \mathrm{kg}$ of $\mathrm{Zn}^{2+}$ concentration was detected, which is well below the limit established by COMMISSION REGULATION (EU) No 10/2011 (25 mg/kg food or food simulant).

\subsection{Biodegradability}

The degradation performances of the PVA/CMC and PVA/CMC/ZnO NPs/ $x \mathrm{GnP}$ composite films with different $\mathrm{ZnO} N \mathrm{Ns}: x \mathrm{GnP}$ ratios in a natural environment are presented in Table 2 . After degradation 
in soil, these films absorbed water, became sticky and soft, and decreased in size. After 20-day degradation in soil, the weight of all samples significantly decreased $(p<0.05)$ because of the presence of water and microorganisms in the soil, and the degradation efficiencies of composite films were lower than those of the PVA/CMC films [45]. Specifically, under these conditions, degradation efficiencies of $32.49 \pm 3.25 \%$ and $30.84 \pm 2.87 \%$ were obtained for the PVA/CMC/ZnO NPs film and the PVA/CMC/ZnO $\mathrm{NPs} / x \mathrm{GnP}$ film with a ZnO NPs: $x \mathrm{GnP}$ mass ratio of 9:1, respectively, this being only $5.47 \%$ and $7.12 \%$ lower than that of the PVA/CMC film $(37.96 \pm 3.60 \%)$, respectively. The higher degradability of the PVA/CMC film was ascribed to the hydrophilicity of its components, PVA and CMC, and the easy penetration of soil moisture into the polymer network, which accelerated water absorption and swelling, and weakened interactions between the materials [25]. The elevated water content promoted the growth of microorganisms during the degradation process and thus made the film susceptible to hydrolysis by soil microorganisms, thereby increasing film weight loss [25]. The slight decrease in degradability observed upon the introduction of $\mathrm{ZnO} N \mathrm{Ns}$ and $x \mathrm{GnP}$ was ascribed to the formation of a denser film structure as a result of the incorporation of these nanofillers between the $x \mathrm{GnP}$ of the PVA/CMC matrix, which decreased water permeability and reduced the swelling degree, thus decreasing the extent of hydrolysis and microbial attack [63]. Further observations revealed that the degradation efficiency increased with increasing $\mathrm{ZnO} N \mathrm{Ns}$ content, possibly because the content of super-hydrophobic $x \mathrm{GnP}$ was relatively low, and hydrophilic ZnO NPs particles containing hydroxyl groups on their surface promoted water absorption-induced swelling, thus facilitating degradation. In addition, as ZnO NPs particles easily formed agglomerates and were unevenly dispersed in the PVA/CMC matrix in high concentrations, they formed a weak area in the composite film, reducing the mechanical strength and accelerating water absorption and swelling to promote degradation [64]. This finding was consistent with the results of Lani et al. [65], who showed that the addition of dispersed phases led to a decrease in polymer biodegradation rate. As shown in Table 2, the degradation efficiency of PVA/CMC and composite films increased with increasing ultrasonication time. The highest values were observed for a treatment time of $60 \mathrm{~min}$, equaling $41.54 \pm 1.46 \%$ for the PVA/CMC film, $37.72 \pm 1.36 \%$ for the PVA/CMC/ZnO NPs composite film, and $34.27 \pm 1.22 \%$ for the PVA/CMC/ZnO NPs/ $x \mathrm{GnP}$ composite film with a $\mathrm{ZnO} N \mathrm{NP}: x \mathrm{GnP}$ ratio of 9:1. The second and third values were $5.23 \%$ and $3.43 \%$ higher than those obtained in the absence of ultrasonic treatment, respectively. The promotional effect of ultrasonication on film degradation was ascribed to the influence of ultrasonication-induced heating and cavitation on the polymer chains of PVA and CMC, which was believed to promote the dispersion of nanofillers, hinder their agglomeration, and thus accelerate nanofiller disintegration and release into soil, facilitating the water absorption-induced swelling of the composite film [29].

\subsection{Preservation Experiment of Strawberries}

\subsubsection{Photographs of Strawberries During the Storage Time}

Figure 11 are the strawberry photographs of typical films during storage time at $25 \pm 1{ }^{\circ} \mathrm{C}$, $55 \pm 5 \%$ RH. During the preservation of strawberries, the PVA/CMC/ZnO NPs $/ x G n P$ film (7:3) showed the best performance out of all blended films during storage, as the appearance of the strawberries changed minimally compared with other groups. On the sixth day, the strawberry wrapped in a PVA/CMC/ZnO NPs/ $x \mathrm{GnP}$ film had no microorganism growth, while the unpacked group had undergone severe decomposition, and the other groups also had varying degrees of mold growth. 
Table 2. Biodegradation rates of the PVA/CMC film and PVA/CMC/ZnO NPs $/ x \mathrm{GnP}$ composite films under different ultrasonication times. ${ }^{*} p<0.05, n=8$ ).

\begin{tabular}{|c|c|c|c|c|c|c|c|c|c|}
\hline \multirow{2}{*}{ Time (Days) } & \multirow{2}{*}{ Ultrasound Time (min) } & \multicolumn{8}{|c|}{ Samples } \\
\hline & & PVA/CMC & 10: 0 & 9:1 & 7:3 & $5: 5$ & 3:7 & 1:9 & 0:10 \\
\hline \multirow{5}{*}{5} & 0 & $14.82 \pm 1.73 \mathrm{Ac}$ & $8.72 \pm 1.02 \mathrm{Bb}$ & $8.01 \pm 1.21 \mathrm{BCb}$ & $6.23 \pm 0.63 \mathrm{BCDb}$ & $6.11 \pm 0.82 \mathrm{BCDb}$ & $4.63 \pm 0.73 \mathrm{CDc}$ & $4.22 \pm 0.38 \mathrm{Dc}$ & $4.02 \pm 1.32 \mathrm{Dc}$ \\
\hline & 15 & $15.74 \pm 1.37 \mathrm{Abc}$ & $9.58 \pm 2.34 \mathrm{Bb}$ & $9.64 \pm 2.09 \mathrm{Bb}$ & $7.24 \pm 1.13 \mathrm{Bb}$ & $7.08 \pm 0.91 \mathrm{Bb}$ & $5.88 \pm 0.56 \mathrm{Bbc}$ & $4.90 \pm 0.44 \mathrm{Bc}$ & $5.57 \pm 0.78 \mathrm{Bbc}$ \\
\hline & 30 & $18.83 \pm 2.11 \mathrm{Aabc}$ & $11.77 \pm 1.78 \mathrm{Bb}$ & $11.56 \pm 1.64 \mathrm{Bab}$ & $9.69 \pm 1.57 \mathrm{BCab}$ & $8.33 \pm 0.75 \mathrm{BCb}$ & $7.49 \pm 0.85 \mathrm{BCabc}$ & $6.46 \pm 0.57 \mathrm{Cbc}$ & $7.72 \pm 1.36 \mathrm{BCbc}$ \\
\hline & 45 & $21.54 \pm 1.57 \mathrm{Aab}$ & $14.90 \pm 1.67 \mathrm{Bab}$ & $14.37 \pm 1.08 \mathrm{Bab}$ & $11.17 \pm 1.27 \mathrm{BCab}$ & $10.57 \pm 1.45 \mathrm{BCab}$ & $8.37 \pm 0.93 \mathrm{Cab}$ & $8.83 \pm 0.89 \mathrm{Cb}$ & $9.64 \pm 0.98 \mathrm{Cab}$ \\
\hline & 60 & $24.62 \pm 1.84 \mathrm{Aa}$ & $18.38 \pm 1.09 \mathrm{Ba}$ & $17.98 \pm 2.37 \mathrm{BCa}$ & $14.65 \pm 2.01 \mathrm{BCDa}$ & $13.29 \pm 1.68 \mathrm{BCDa}$ & $10.12 \pm 1.27 \mathrm{Da}$ & $12.34 \pm 1.38 \mathrm{CDa}$ & $12.78 \pm 1.37 \mathrm{BCDa}$ \\
\hline \multirow{5}{*}{10} & 0 & $23.93 \pm 2.31 \mathrm{Ab}$ & $17.96 \pm 2.83 \mathrm{Ba}$ & $17.29 \pm 1.73 \mathrm{BCa}$ & $14.82 \pm 1.03 \mathrm{BCb}$ & $13.23 \pm 2.02 \mathrm{BCa}$ & $11.83 \pm 1.36 \mathrm{BCb}$ & $11.20 \pm 1.20 \mathrm{Ca}$ & $11.11 \pm 1.05 \mathrm{Ca}$ \\
\hline & 15 & $25.47 \pm 1.87 \mathrm{Ab}$ & $19.24 \pm 1.14 \mathrm{Ba}$ & $18.74 \pm 1.46 \mathrm{Ba}$ & $15.03 \pm 1.27 \mathrm{BCab}$ & $14.62 \pm 1.78 \mathrm{BCa}$ & $12.67 \pm 0.98 \mathrm{Cab}$ & $12.34 \pm 1.44 \mathrm{Ca}$ & $11.95 \pm 1.18 \mathrm{Ca}$ \\
\hline & 30 & $26.99 \pm 1.37 \mathrm{Aab}$ & $21.65 \pm 1.57 \mathrm{Ba}$ & $19.26 \pm 1.39 \mathrm{BCa}$ & $15.98 \pm 1.28 \mathrm{CDab}$ & $15.24 \pm 1.62 \mathrm{CDa}$ & $13.46 \pm 1.02 \mathrm{Dab}$ & $13.18 \pm 1.30 \mathrm{Da}$ & $12.76 \pm 1.33 \mathrm{Da}$ \\
\hline & 45 & $28.63 \pm 1.59 \mathrm{Aab}$ & $22.97 \pm 1.63 \mathrm{Ba}$ & $20.98 \pm 1.58 \mathrm{BCa}$ & $16.74 \pm 1.33 \mathrm{CDab}$ & $16.32 \pm 1.58 \mathrm{CDa}$ & $14.79 \pm 1.26 \mathrm{Dab}$ & $14.67 \pm 1.28 \mathrm{Da}$ & $13.39 \pm 1.49 \mathrm{Da}$ \\
\hline & 60 & $30.19 \pm 1.62 \mathrm{Aa}$ & $23.88 \pm 1.77 \mathrm{Ba}$ & $21.75 \pm 2.01 \mathrm{BCa}$ & $18.66 \pm 1.49 \mathrm{BCDa}$ & $17.95 \pm 1.66 \mathrm{CDa}$ & $16.03 \pm 1.37 \mathrm{CDa}$ & $15.29 \pm 1.67 \mathrm{Da}$ & $14.28 \pm 1.52 \mathrm{Da}$ \\
\hline \multirow{5}{*}{15} & 0 & $30.82 \pm 3.02 \mathrm{Aa}$ & $23.93 \pm 2.86 \mathrm{AB}$ & $21.56 \pm 3.19 \mathrm{BCa}$ & $20.39 \pm 2.63 \mathrm{BCa}$ & $18.30 \pm 2.53 \mathrm{BCa}$ & $17.94 \pm 1.94 \mathrm{BCa}$ & $15.34 \pm 1.50 \mathrm{BCa}$ & $14.38 \pm 1.44 \mathrm{Ca}$ \\
\hline & 15 & $31.24 \pm 2.47 \mathrm{Aa}$ & $25.13 \pm 1.73 \mathrm{Ba}$ & $22.91 \pm 1.01 \mathrm{BCa}$ & $21.57 \pm 0.75 \mathrm{BCDa}$ & $19.42 \pm 1.10 \mathrm{CDEa}$ & $19.02 \pm 1.88 \mathrm{CDEa}$ & $16.72 \pm 0.47 \mathrm{DEa}$ & $15.73 \pm 1.32 \mathrm{Ea}$ \\
\hline & 30 & $33.19 \pm 2.34 \mathrm{Aa}$ & $26.79 \pm 1.68 \mathrm{Ba}$ & $24.04 \pm 1.27 \mathrm{BCa}$ & $22.82 \pm 1.03 \mathrm{BCDa}$ & $20.79 \pm 1.78 \mathrm{CDEa}$ & $19.87 \pm 1.21 \mathrm{CDEa}$ & $17.92 \pm 0.87 \mathrm{DEa}$ & $16.92 \pm 1.29 \mathrm{Ea}$ \\
\hline & 45 & $34.68 \pm 2.18 \mathrm{Aa}$ & $27.36 \pm 1.29 \mathrm{Ba}$ & $25.69 \pm 1.18 \mathrm{BCa}$ & $24.29 \pm 1.28 \mathrm{BCa}$ & $21.94 \pm 1.62 \mathrm{CDa}$ & $20.75 \pm 1.34 \mathrm{CDa}$ & $18.37 \pm 0.92 \mathrm{Da}$ & $17.02 \pm 1.45 \mathrm{Da}$ \\
\hline & 60 & $35.72 \pm 2.57 \mathrm{Aa}$ & $29.61 \pm 1.11 \mathrm{Ba}$ & $26.83 \pm 1.37 \mathrm{BCa}$ & $25.63 \pm 1.39 \mathrm{BCa}$ & $23.48 \pm 1.56 \mathrm{CDa}$ & $21.99 \pm 1.55 \mathrm{CDa}$ & $19.28 \pm 1.25 \mathrm{Da}$ & $18.54 \pm 1.09 \mathrm{Da}$ \\
\hline \multirow{5}{*}{20} & 0 & $37.96 \pm 3.60 \mathrm{Aa}$ & $32.49 \pm 3.25 \mathrm{ABa}$ & $30.84 \pm 2.87 \mathrm{ABa}$ & $27.93 \pm 2.62 \mathrm{BCa}$ & $24.50 \pm 2.43 \mathrm{BCa}$ & $23.26 \pm 2.30 \mathrm{BCa}$ & $21.34 \pm 1.95 \mathrm{Ca}$ & $20.83 \pm 2.01 \mathrm{Ca}$ \\
\hline & 15 & $38.88 \pm 1.67 \mathrm{Aa}$ & $33.68 \pm 1 \mathrm{a} .09 \mathrm{Aa}$ & $31.79 \pm 1.78 \mathrm{BCa}$ & $28.62 \pm 1.73 \mathrm{BCDa}$ & $25.50 \pm 2.02 \mathrm{CDa}$ & $24.69 \pm 2.17 \mathrm{CDa}$ & $22.68 \pm 1.78 \mathrm{Da}$ & $21.87 \pm 1.76 \mathrm{Da}$ \\
\hline & 30 & $39.29 \pm 2.04 \mathrm{Aa}$ & $35.13 \pm 1.23 \mathrm{ABa}$ & $32.55 \pm 1.69 \mathrm{BCa}$ & $29.17 \pm 1.38 \mathrm{CDa}$ & $26.79 \pm 1.38 \mathrm{DEa}$ & $25.61 \pm 1.68 \mathrm{DEa}$ & $23.47 \pm 1.64 \mathrm{Ea}$ & $23.04 \pm 1.58 \mathrm{Ea}$ \\
\hline & 45 & $40.76 \pm 1.78 \mathrm{Aa}$ & $36.62 \pm 1.28 \mathrm{ABa}$ & $33.49 \pm 1.34 \mathrm{BCa}$ & $30.56 \pm 1.22 \mathrm{CDa}$ & $27.15 \pm 1.47 \mathrm{DEa}$ & $27.01 \pm 1.57 \mathrm{DEa}$ & $24.39 \pm 1.55 \mathrm{Ea}$ & $24.65 \pm 1.21 \mathrm{Ea}$ \\
\hline & 60 & $41.54 \pm 1.46 \mathrm{Aa}$ & $37.72 \pm 1.36 \mathrm{ABa}$ & $34.27 \pm 1.22 \mathrm{BCa}$ & $31.47 \pm 1.35 \mathrm{CDa}$ & $28.86 \pm 1.58 \mathrm{DEa}$ & $28.34 \pm 1.34 \mathrm{DEa}$ & $25.15 \pm 1.28 \mathrm{Ea}$ & $25.81 \pm 1.33 \mathrm{Ea}$ \\
\hline
\end{tabular}

Values with the same letter are not statistically different, according to Duncan's multiple range test at $p<0.05 . \mathrm{a}, \mathrm{b}$, c: mean values with the same letter in the same column are not significantly different. $(p>0.05)(n=8)$. A, B, C, D: mean values with the same letter in the same row are not significantly different. $(p>0.05)(n=8)$ 


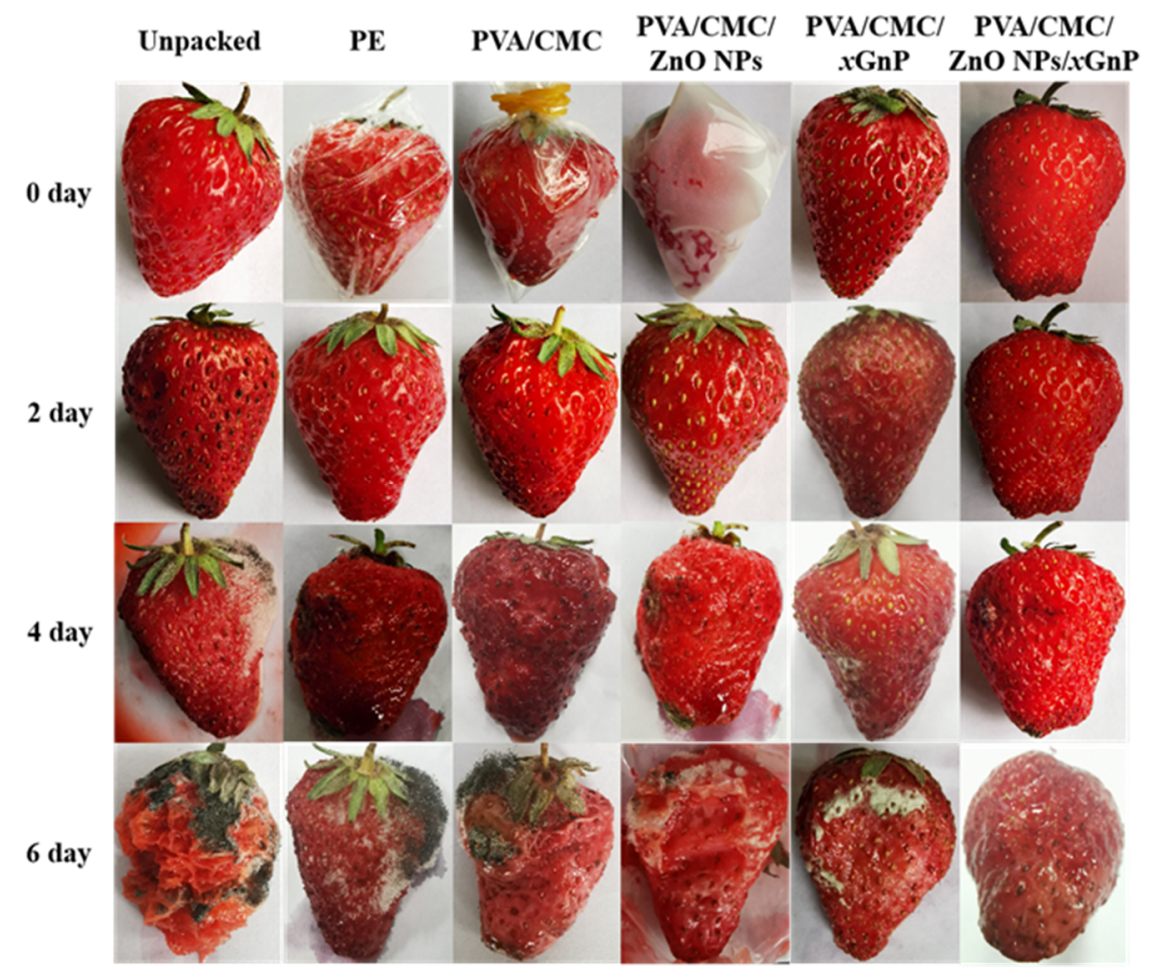

Figure 11. Strawberry photographs of typical films during storage time at $25 \pm 1{ }^{\circ} \mathrm{C}, 55 \pm 5 \% \mathrm{RH}$.

\subsubsection{Strawberry Properties}

Weight loss is one of the important indexes to judge the freshness of a strawberry. As shown in Table 3, with the extension of storage time, the weightlessness rate of strawberries also showed an increasing trend. During the storage process of strawberries, the body will undergo respiration and evaporation, so that its own water will be lost. The unpacked groups exposed to the environment directly experienced rapid moisture loss, and the poor barrier properties of PE films could allow gasses such as oxygen from the air to permeate, boosting the growth and reproduction of microorganisms on the strawberries and bringing about the rapid decay of fresh fruits. Over the same storage time, the weight loss rates of the unpacked group and the PE film group were relatively high, which were $37.67 \pm 1.54 \%$ and $35.62 \pm 1.68 \%$, respectively. In the other groups of blend films, the strawberries wrapped in PVA/CMC/ZnO NPs/ $x \mathrm{GnP}$ (7:3) films underwent the least weight loss. On the sixth day, their weight loss rate was $18.66 \pm 1.99 \%, 19.01 \%$ lower than the unpacked groups. This may be because the composite films on the strawberry surface acted as a semipermeable barrier against gas and water, explaining why PVA/CMC/ZnO NPs/ $x \mathrm{GnP}(7: 3)$ films can effectively control the strawberry's metabolism and water loss.

The hardness of a strawberry is determined by the pectin content in the pulp. The hardness not only affects the taste, but also directly affects the transportation and processing cost. Table 3 shows the trend of strawberry hardness with time in different treatment groups. Starting from the second day, the hardness values of strawberries in each treatment group were significantly different, and the hardness of the unpacked group decreased the fastest, while the hardness of the PVA/CMC/ZnO $\mathrm{NPs} / x \mathrm{GnP}$ film group decreased significantly less than that of the unpacked group. On the sixth day, the hardness of the PVA/CMC/ZnO NPs/ $x \mathrm{GnP}$ film group was $0.41071 \pm 0.17647,0.41071$ higher than that of the unpacked group. Moreover, the unpacked group and the PE film group always presented lower firmness values compared with the composite film groups, as strawberries soften by decay. 
Table 3. The strawberry preservation indexes of typical films in terms of weight loss ratio, firmness, content of total soluble solids and titration acid. $(p>0.05)(n=6)$.

\begin{tabular}{|c|c|c|c|c|c|c|c|}
\hline Strawberry Properties & $\begin{array}{c}\begin{array}{l}\text { Storage Time } \\
\text { (Days) }\end{array} \\
\end{array}$ & Unpacked & PE & PVA/CMC & $\begin{array}{c}\text { PVA/CMC/ } \\
\text { ZnO NPs }\end{array}$ & $\mathrm{PVA} / \mathrm{CMC} / x \mathrm{GnP}$ & $\begin{array}{c}\text { PVA/CMC/ } \\
\text { ZnO NPs } / x \text { GnP } \\
\end{array}$ \\
\hline \multirow{3}{*}{ Weight loss ratio (\%) } & 2 & $3.34 \pm 0.11 \mathrm{Ac}$ & $3.01 \pm 0.53 \mathrm{Ac}$ & $2.98 \pm 0.47 \mathrm{Ac}$ & $2.57 \pm 0.77 \mathrm{Ab}$ & $2.87 \pm 1.04 \mathrm{Ac}$ & $2.46 \pm 0.27 \mathrm{Ab}$ \\
\hline & 4 & $12.92 \pm 1.23 \mathrm{Ab}$ & $12.58 \pm 0.98 \mathrm{Ab}$ & $11.79 \pm 1.22 \mathrm{ABb}$ & $8.54 \pm 1.38 \mathrm{ABb}$ & $10.86 \pm 1.47 \mathrm{ABb}$ & $7.51 \pm 1.55 \mathrm{Bb}$ \\
\hline & 6 & $37.67 \pm 1.54 \mathrm{Aa}$ & $35.62 \pm 1.68 \mathrm{ABa}$ & $29.99 \pm 2.49 \mathrm{BCa}$ & $23.67 \pm 1.79 \mathrm{Ca}$ & $27.63 \pm 1.82 \mathrm{CDa}$ & $18.66 \pm 1.99 \mathrm{Da}$ \\
\hline \multirow{4}{*}{ Firmness(Normalized) } & 0 & $0.91964 \pm 0.89706 \mathrm{Aa}$ & $0.98214 \pm 0.67647 \mathrm{Aa}$ & $0.9375 \pm 0.98529 \mathrm{Aa}$ & $0.92857 \pm 1 \mathrm{Aa}$ & $0.94643 \pm 0.10294 \mathrm{Aa}$ & $1 \pm 0.95588 \mathrm{Aa}$ \\
\hline & 2 & $0.6875 \pm 0.39706 \mathrm{Aa}$ & $0.79464 \pm 0.83824 \mathrm{Aa}$ & $0.73214 \pm 0.52941 \mathrm{Aa}$ & $0.77679 \pm 0.55882 \mathrm{Aa}$ & $0.75893 \pm 0.67647 \mathrm{Aa}$ & $0.80357 \pm 0.70588 \mathrm{Aa}$ \\
\hline & 4 & $0.36607 \pm 0.47059 \mathrm{Aa}$ & $0.45536 \pm 0.89706 \mathrm{Aa}$ & $0.47321 \pm 0.14706 \mathrm{Aa}$ & $0.51786 \pm 0.32353 \mathrm{Aa}$ & $0.5 \pm 0.60294 \mathrm{Aa}$ & $0.55357 \pm 0.97059 \mathrm{Aa}$ \\
\hline & 6 & $0 \pm 0 \mathrm{Aa}$ & $0.125 \pm 0.02941 \mathrm{ABa}$ & $0.1875 \pm 0.11765 \mathrm{ABa}$ & $0.28571 \pm 0.23529 \mathrm{ABa}$ & $0.24107 \pm 0.22059 \mathrm{ABa}$ & $0.41071 \pm 0.17647 \mathrm{Ba}$ \\
\hline \multirow{4}{*}{ Content of Total Soluble Solids (\%) } & 0 & $11 \pm 0.79 \mathrm{Aa}$ & $11 \pm 1.02 \mathrm{Aa}$ & $12 \pm 1.23 \mathrm{Aa}$ & $11 \pm 1.24 \mathrm{Aa}$ & $11 \pm 1.28 \mathrm{Aa}$ & $12 \pm 1.25 \mathrm{Aa}$ \\
\hline & 2 & $9 \pm 0.23 \mathrm{Aab}$ & $9.5 \pm 0.67 \mathrm{Aab}$ & $10 \pm 0.92 \mathrm{Aab}$ & $10 \pm 0.92 \mathrm{Aab}$ & $10.5 \pm 1.05 \mathrm{Ab}$ & $11 \pm 1.38 \mathrm{Aab}$ \\
\hline & 4 & $6.5 \pm 0.27 \mathrm{Abc}$ & $7 \pm 0.48 \mathrm{ABbc}$ & $7.5 \pm 0.38 \mathrm{ABbc}$ & $8 \pm 0.67 \mathrm{Bbc}$ & $7 \pm 0.89 \mathrm{BC}$ & $9.5 \pm 0.79 \mathrm{Bab}$ \\
\hline & 6 & $4 \pm 0.87 \mathrm{Ac}$ & $5 \pm 0.52 \mathrm{ABC}$ & $6 \pm 0.45 \mathrm{ABC}$ & $6.5 \pm 0.58 \mathrm{ABCC}$ & $6.5 \pm 0.57 \mathrm{BCC}$ & $8 \pm 0.35 \mathrm{Cb}$ \\
\hline \multirow{4}{*}{ Titratable Acidity (\%) } & 0 & $0.84 \pm 0.21 \mathrm{Aa}$ & $0.84 \pm 0.22 \mathrm{Aa}$ & $0.82 \pm 0.14 \mathrm{Aa}$ & $0.85 \pm 0.17 \mathrm{Aa}$ & $0.82 \pm 0.01 \mathrm{Aa}$ & $0.84 \pm 0.12 \mathrm{Aa}$ \\
\hline & 2 & $0.75 \pm 0.18 \mathrm{Aa}$ & $0.76 \pm 0.17 \mathrm{Aa}$ & $0.75 \pm 0.12 \mathrm{Aa}$ & $0.79 \pm 0.12 \mathrm{Aa}$ & $0.75 \pm 0.13 \mathrm{Aa}$ & $0.80 \pm 0.14 \mathrm{Aa}$ \\
\hline & 4 & $0.55 \pm 0.11 \mathrm{Aa}$ & $0.58 \pm 0.12 \mathrm{Aa}$ & $0.56 \pm 0.05 \mathrm{Aab}$ & $0.60 \pm 0.07 \mathrm{Aa}$ & $0.57 \pm 0.06 \mathrm{Aab}$ & $0.76 \pm 0.08 \mathrm{Aa}$ \\
\hline & 6 & $0.31 \pm 0.08 \mathrm{Aa}$ & $0.33 \pm 0.10 \mathrm{Aa}$ & $0.33 \pm 0.03 \mathrm{Ab}$ & $0.42 \pm 0.01 \mathrm{Aa}$ & $0.35 \pm 0.04 \mathrm{Ab}$ & $0.53 \pm 0.06 \mathrm{Aa}$ \\
\hline
\end{tabular}

Values with the same letter are not statistically different, according to Duncan's multiple range test at $p<0.05 . \mathrm{a}, \mathrm{b}$, c: mean values with the same letter in the same column are not significantly different. $(p>0.05)(n=6)$. A, B, C, D: mean values with the same letter in the same row are not significantly different. $(p>0.05)(n=6)$. 
TSS has a close relationship with fruit maturity and respiration rate, which is one of the evaluation indexes of the strawberry preservation effect. The soluble solids contents of strawberries in different treatment groups during the whole storage period are shown in Table 3. During the first 6 days of the storage period, the content of soluble solids decreased rapidly (down 63.7\%) in the unpacked group, which may be because after the post-ripening stage of the fruit, the metabolic rate accelerated and the consumption of soluble solids accelerated. The content of soluble solids decreased slowly (down 33.3\%) in the PVA/CMC/ZnO NPs/ $x$ GnP film group. During the whole storage, the content of soluble solids remained high in the composite film group, significantly higher than that in the unpacked group and the PE film group $(p<0.05)$. This shows that strawberries can have inhibited metabolisms and reduced consumptions of soluble solids after compound coating.

The titration acid content affects the flavor quality of strawberry fruit, which is recognized as one of the important indicators for evaluating the effect of strawberry preservation. Its main component is organic acid. The titration acid content of the composite film group and the unpacked group was not obvious at the beginning. However, from the second day, the change in the titration acid content in each group began to be significant, especially in the unpacked and PE groups. On the sixth day, the titration acid contents of the unpacked group and PE group were $0.31 \pm 0.08 \%$ and $0.33 \pm 0.10 \%$, which were much lower than that of the PVA/CMC/ZnO NPs/ $x$ GnP film group $(0.53 \pm 0.06 \%)$. This indicates that the breathing and metabolic rate were fast in this period. In addition, the ZnO NPs and $x \mathrm{GnP}$ film groups had little effect on the titration acid content in the strawberries.

\section{Conclusions}

The target of our work was to design a novel film for food packaging. In our work, PVA/CMC/ZnO NPs/ $x$ GnP composite films were successfully fabricated by ultrasonication and solution casting, and showed the best overall performance (e.g., strong antibacterial activity against both Gram-positive and Gram-negative foodborne pathogenic bacteria). The best preservation effects for strawberries were as follows: the strawberries wrapped in PVA/CMC/ZnO NPs/ $x \mathrm{GnP}$ (7:3) films showed the least weight loss (19.01\% less than the unpacked groups on the sixth day), which was observed at a ZnO NPs: $x \mathrm{GnP}$ mass ratio of 7:3. In addition, the PVA/CMC/ZnO NPs/ $x$ GnP composite film (ZnO NPs: $x$ GnP mass ratio of 7:3) had a low water vapor transmission rate. By studying the effects of different ultrasonic times on the properties of composite membranes, we found that ultrasonication improved the mechanical properties of composite films and, in combination with traditional film preparation methods and at an ultrasonication time of $30 \mathrm{~min}$, the pure PVA/CMC film exhibited a strain of $165.60 \pm 8.88 \%$, which was $31.57 \%$ higher than that observed for the non-ultrasonicated film. At the same time, ultrasonic treatment also significantly improves biodegradability. In a word, it was concluded to be well suited for the production of composite films with enhanced mechanical, antibacterial, biodegradability and barrier properties for commercial food packaging applications.

Author Contributions: Writing-original draft preparation, T.J.; writing-review and editing, R.Z.; X.D.; formal analysis, D.E.S.; data curation, S.A.; visualization, S.L.; project administration, Y.L.; supervision. All authors have read and agreed to the published version of the manuscript.

Funding: This work was supported by National Natural Science Foundation of China (51703147), Sichuan Science and Technology Program (2018RZ0034), and Natural Science Fund of Education Department of Sichuan Province (16ZB0044 and 035Z1373).

Conflicts of Interest: The authors declare no conflict of interest. 


\section{Appendix A}

Table A1. Apparent colors and light transmittance of the PVA/CMC film and the PVA/CMC/ZnO NPs/ $x$ GnP composite films under different ultrasonication times. $\left({ }^{*} p<0.05, n=8\right)$.

\begin{tabular}{|c|c|c|c|c|c|c|c|c|c|}
\hline \multirow{2}{*}{$\begin{array}{l}\text { Apparent Colors and } \\
\text { Light Transmittance }\end{array}$} & \multirow{2}{*}{ Ultrasound Time ( $\mathrm{min}$ ) } & \multicolumn{8}{|c|}{ Samples } \\
\hline & & PVA/CMC & 10: 0 & 9:1 & $7: 3$ & $5: 5$ & 3:7 & 1:9 & $0: 10$ \\
\hline \multirow{5}{*}{$\mathrm{L}$} & 0 & $90.78 \pm 0.26 \mathrm{Aa}$ & $91.91 \pm 0.35 \mathrm{Aa}$ & $48.70 \pm 1.12 \mathrm{Ba}$ & $38.91 \pm 0.12 \mathrm{Db}$ & $38.56 \pm 0.30 \mathrm{Db}$ & $40.69 \pm 0.19 \mathrm{Ca}$ & $41.48 \pm 0.10 \mathrm{Cab}$ & $41.34 \pm 0.16 \mathrm{Ca}$ \\
\hline & 15 & $91.31 \pm 0.13 \mathrm{Aa}$ & $91.40 \pm 0.12 \mathrm{Aa}$ & $48.54 \pm 1.67 \mathrm{Ba}$ & $39.54 \pm 0.12 \mathrm{Cb}$ & $40.02 \pm 0.34 \mathrm{Ca}$ & $40.56 \pm 0.26 \mathrm{Ca}$ & $41.69 \pm 0.11 \mathrm{Cab}$ & $41.56 \pm 0.13 \mathrm{Ca}$ \\
\hline & 30 & $91.15 \pm 0.08 \mathrm{Aa}$ & $91.36 \pm 0.14 \mathrm{Aa}$ & $44.57 \pm 2.00 \mathrm{Bab}$ & $40.60 \pm 0.36 \mathrm{Ca}$ & $39.99 \pm 0.21 \mathrm{Ca}$ & $39.45 \pm 0.91 \mathrm{Ca}$ & $41.29 \pm 0.18 \mathrm{Cb}$ & $41.24 \pm 0.07 \mathrm{Ca}$ \\
\hline & 45 & $90.93 \pm 0.14 \mathrm{Aa}$ & $91.94 \pm 0.15 \mathrm{Aa}$ & $42.70 \pm 1.81 \mathrm{Bb}$ & $39.79 \pm 0.42 \mathrm{CDab}$ & $38.87 \pm 0.16 \mathrm{Db}$ & $39.84 \pm 0.80 \mathrm{CDa}$ & $41.65 \pm 0.04 \mathrm{BCab}$ & $41.45 \pm 0.08 \mathrm{BCa}$ \\
\hline & 60 & $90.90 \pm 0.10 \mathrm{Aa}$ & $92.04 \pm 0.09 \mathrm{Aa}$ & $42.53 \pm 0.85 \mathrm{Bb}$ & $39.39 \pm 0.25 \mathrm{Cb}$ & $39.84 \pm 0.14 \mathrm{Ca}$ & $38.94 \pm 0.55 \mathrm{Ca}$ & $41.77 \pm 0.14 \mathrm{Ba}$ & $41.40 \pm 0.22 \mathrm{Ba}$ \\
\hline \multirow{5}{*}{ a } & 0 & $0.91 \pm 0.15 \mathrm{Aa}$ & $0.87 \pm 0.17 \mathrm{Aa}$ & $-4.48 \pm 0.10 \mathrm{CDa}$ & $-4.12 \pm 0.10 \mathrm{BCa}$ & $-3.89 \pm 0.15 \mathrm{Ba}$ & $-4.47 \pm 0.10 \mathrm{CDa}$ & $-4.30 \pm 0.11 \mathrm{BCDa}$ & $-4.56 \pm 0.09 \mathrm{Db}$ \\
\hline & 15 & $0.95 \pm 0.08 \mathrm{Aa}$ & $1.08 \pm 0.11 \mathrm{Aa}$ & $-4.42 \pm 0.07 \mathrm{BCDa}$ & $-4.17 \pm 0.15 \mathrm{BCa}$ & $-4.06 \pm 0.11 \mathrm{Ba}$ & $-4.46 \pm 0.10 \mathrm{CDa}$ & $-4.40 \pm 0.09 \mathrm{BCDa}$ & $-4.58 \pm 0.10 \mathrm{Db}$ \\
\hline & 30 & $0.88 \pm 0.10 \mathrm{Aa}$ & $0.93 \pm 0.13 \mathrm{Aa}$ & $-4.38 \pm 0.14 \mathrm{Ba}$ & $-4.35 \pm 0.09 \mathrm{Ba}$ & $-4.10 \pm 0.09 \mathrm{Ba}$ & $-4.37 \pm 0.08 \mathrm{Ba}$ & $-4.36 \pm 0.09 \mathrm{Ba}$ & $-4.07 \pm 0.11 \mathrm{Ba}$ \\
\hline & 45 & $0.74 \pm 0.09 \mathrm{Aa}$ & $0.83 \pm 0.08 \mathrm{Aa}$ & $-4.37 \pm 0.15 \mathrm{BCa}$ & $-4.16 \pm 0.07 \mathrm{BCa}$ & $-4.07 \pm 0.02 \mathrm{Ba}$ & $-4.52 \pm 0.09 \mathrm{Ca}$ & $-4.46 \pm 0.09 \mathrm{Ca}$ & $-4.29 \pm 0.17 \mathrm{BCab}$ \\
\hline & 60 & $0.63 \pm 0.05 \mathrm{Aa}$ & $0.77 \pm 0.07 \mathrm{Aa}$ & $-4.53 \pm 0.15 \mathrm{Ca}$ & $-4.15 \pm 0.04 \mathrm{Ba}$ & $-4.08 \pm 0.13 \mathrm{Ba}$ & $-4.54 \pm 0.10 \mathrm{Ca}$ & $-4.55 \pm 0.11 \mathrm{Ca}$ & $-4.00 \pm 0.03 \mathrm{Ba}$ \\
\hline \multirow{5}{*}{ b } & 0 & $-3.87 \pm 0.21 \mathrm{Eab}$ & $-3.72 \pm 0.10 \mathrm{~Eb}$ & $2.88 \pm 0.13 \mathrm{Aa}$ & $1.71 \pm 0.09 \mathrm{Ca}$ & $1.32 \pm 0.10 \mathrm{Da}$ & $1.77 \pm 0.01 \mathrm{Cb}$ & $1.77 \pm 0.09 \mathrm{Ca}$ & $2.18 \pm 0.01 \mathrm{Ba}$ \\
\hline & 15 & $-4.22 \pm 0.09 \mathrm{Db}$ & $-4.17 \pm 0.11 \mathrm{Db}$ & $3.12 \pm 0.17 \mathrm{Aa}$ & $1.79 \pm 0.11 \mathrm{BCa}$ & $1.46 \pm 0.10 \mathrm{Ca}$ & $1.95 \pm 0.01 \mathrm{Bab}$ & $1.90 \pm 0.10 \mathrm{Ba}$ & $2.11 \pm 0.10 \mathrm{Ba}$ \\
\hline & 30 & $-3.89 \pm 0.07 \mathrm{Dab}$ & $-3.99 \pm 0.13 \mathrm{Db}$ & $2.93 \pm 0.33 \mathrm{Aa}$ & $1.88 \pm 0.11 \mathrm{BCa}$ & $1.46 \pm 0.10 \mathrm{Ca}$ & $1.94 \pm 0.06 \mathrm{BCab}$ & $2.03 \pm 0.09 \mathrm{Ba}$ & $1.50 \pm 0.10 \mathrm{Cb}$ \\
\hline & 45 & $-3.79 \pm 0.12 \mathrm{Cab}$ & $-3.85 \pm 0.13 \mathrm{Cb}$ & $2.54 \pm 0.35 \mathrm{Aa}$ & $1.76 \pm 0.09 \mathrm{Ba}$ & $1.51 \pm 0.17 \mathrm{Ba}$ & $2.02 \pm 0.08 \mathrm{ABa}$ & $1.71 \pm 0.10 \mathrm{Ba}$ & $1.59 \pm 0.15 \mathrm{Bb}$ \\
\hline & 60 & $-3.67 \pm 0.03 \mathrm{Ea}$ & $-2.78 \pm 0.22 \mathrm{Da}$ & $2.89 \pm 0.30 \mathrm{Aa}$ & $1.66 \pm 0.10 \mathrm{BCa}$ & $1.65 \pm 0.11 \mathrm{BCa}$ & $2.05 \pm 0.08 \mathrm{Ba}$ & $1.78 \pm 0.08 \mathrm{Ba}$ & $1.22 \pm 0.08 \mathrm{Cb}$ \\
\hline \multirow{5}{*}{$\Delta \mathrm{E}$} & 0 & $1.13 \pm 0.04 \mathrm{~Eb}$ & $2.11 \pm 0.22 \mathrm{~Eb}$ & $42.35 \pm 0.95 \mathrm{Db}$ & $51.76 \pm 0.11 \mathrm{ABa}$ & $52.03 \pm 0.26 \mathrm{Aa}$ & $50.05 \pm 0.16 \mathrm{BCa}$ & $49.25 \pm 0.07 \mathrm{Bab}$ & $49.46 \pm 0.14 \mathrm{Ba}$ \\
\hline & 15 & $1.41 \pm 0.08 \mathrm{Da}$ & $1.45 \pm 0.07 \mathrm{Dc}$ & $42.54 \pm 1.44 \mathrm{Cb}$ & $51.15 \pm 0.10 \mathrm{Aa}$ & $50.62 \pm 0.29 \mathrm{Ab}$ & $50.19 \pm 0.22 \mathrm{ABa}$ & $49.07 \pm 0.10 \mathrm{Bb}$ & $49.25 \pm 0.09 \mathrm{Ba}$ \\
\hline & 30 & $1.31 \pm 0.03 \mathrm{Ca}$ & $1.55 \pm 0.08 \mathrm{Cc}$ & $46.39 \pm 1.69 \mathrm{Bab}$ & $50.13 \pm 0.31 \mathrm{Ab}$ & $50.65 \pm 0.19 \mathrm{Ab}$ & $51.28 \pm 0.81 \mathrm{Aa}$ & $49.47 \pm 0.15 \mathrm{Aa}$ & $49.43 \pm 0.06 \mathrm{Aa}$ \\
\hline & 45 & $1.32 \pm 0.04 \mathrm{Da}$ & $2.12 \pm 0.15 \mathrm{Db}$ & $48.16 \pm 1.54 \mathrm{Ca}$ & $50.90 \pm 0.37 \mathrm{ABab}$ & $51.76 \pm 0.15 \mathrm{Aa}$ & $50.92 \pm 0.52 \mathrm{ABa}$ & $49.09 \pm 0.03 \mathrm{BCb}$ & $49.25 \pm 0.09 \mathrm{BCa}$ \\
\hline & 60 & $1.41 \pm 0.04 \mathrm{Da}$ & $2.76 \pm 0.13 \mathrm{Da}$ & $48.40 \pm 1.13 \mathrm{Ca}$ & $51.28 \pm 0.21 \mathrm{Aa}$ & $50.83 \pm 0.11 \mathrm{ABb}$ & $51.81 \pm 0.79 \mathrm{Aa}$ & $48.99 \pm 0.11 \mathrm{Cb}$ & $49.23 \pm 0.19 \mathrm{BCa}$ \\
\hline \multirow{5}{*}{$\mathrm{T}_{280}$} & 0 & $82.38 \pm 0.74 \mathrm{Aa}$ & $27.69 \pm 0.30 \mathrm{Ga}$ & $31.32 \pm 1.02 \mathrm{Fa}$ & $37.75 \pm 0.87 \mathrm{Eab}$ & $39.97 \pm 0.93 \mathrm{Eab}$ & $46.31 \pm 0.90 \mathrm{Dab}$ & $53.01 \pm 0.84 \mathrm{Cb}$ & $61.19 \pm 1.37 \mathrm{Bab}$ \\
\hline & 15 & $82.12 \pm 0.70 \mathrm{Aa}$ & $27.29 \pm 0.42 \mathrm{Ha}$ & $31.24 \pm 0.79 \mathrm{Ga}$ & $37.20 \pm 0.36 \mathrm{Fab}$ & $39.67 \pm 0.83 \mathrm{Eab}$ & $45.63 \pm 0.73 \mathrm{Dab}$ & $52.31 \pm 0.79 \mathrm{Cb}$ & $60.36 \pm 0.70 \mathrm{Bab}$ \\
\hline & 30 & $81.78 \pm 0.82 \mathrm{Aa}$ & $26.72 \pm 0.37 \mathrm{Ha}$ & $30.67 \pm 1.12 \mathrm{Ga}$ & $35.62 \pm 0.67 \mathrm{Fb}$ & $38.32 \pm 1.00 \mathrm{~Eb}$ & $45.21 \pm 0.49 \mathrm{Db}$ & $51.04 \pm 0.38 \mathrm{Cb}$ & $58.63 \pm 0.84 \mathrm{Bb}$ \\
\hline & 45 & $82.01 \pm 0.39 \mathrm{Aa}$ & $27.33 \pm 0.62 \mathrm{Ga}$ & $30.98 \pm 0.93 \mathrm{Fa}$ & $36.35 \pm 0.55 \mathrm{~Eb}$ & $38.70 \pm 0.87 \mathrm{~Eb}$ & $45.23 \pm 0.77 \mathrm{Db}$ & $51.73 \pm 0.67 \mathrm{Cb}$ & $58.32 \pm 1.03 \mathrm{Bb}$ \\
\hline & 60 & $82.89 \pm 0.69 \mathrm{Aa}$ & $28.36 \pm 0.44 \mathrm{Ha}$ & $32.92 \pm 1.32 \mathrm{Ga}$ & $39.23 \pm 0.98 \mathrm{Fa}$ & $42.83 \pm 0.89 \mathrm{Ea}$ & $48.33 \pm 0.73 \mathrm{Da}$ & $55.93 \pm 0.56 \mathrm{Ca}$ & $63.84 \pm 0.73 \mathrm{Ba}$ \\
\hline \multirow{5}{*}{$\mathrm{T}_{600}$} & 0 & $88.60 \pm 0.82 \mathrm{Aa}$ & $57.98 \pm 0.83 \mathrm{Bab}$ & $50.57 \pm 0.71 \mathrm{Ca}$ & $47.77 \pm 0.46 \mathrm{Dab}$ & $42.08 \pm 0.75 \mathrm{~Eb}$ & $37.97 \pm 0.33 \mathrm{Fab}$ & $32.58 \pm 0.74 \mathrm{Gab}$ & $30.68 \pm 0.50 \mathrm{~Gb}$ \\
\hline & 15 & $88.83 \pm 0.64 \mathrm{Aa}$ & $57.31 \pm 0.83 \mathrm{Bab}$ & $49.32 \pm 0.62 \mathrm{Ca}$ & $47.02 \pm 1.30 \mathrm{Cb}$ & $41.74 \pm 0.54 \mathrm{Db}$ & $37.05 \pm 0.76 \mathrm{~Eb}$ & $32.02 \pm 0.66 \mathrm{Fb}$ & $30.47 \pm 0.56 \mathrm{Fb}$ \\
\hline & 30 & $88.12 \pm 0.62 \mathrm{Aa}$ & $56.36 \pm 0.54 \mathrm{Bb}$ & $48.21 \pm 1.42 \mathrm{Ca}$ & $45.00 \pm 0.89 \mathrm{Db}$ & $40.12 \pm 0.48 \mathrm{~Eb}$ & $36.49 \pm 0.73 \mathrm{Fb}$ & $30.18 \pm 0.75 \mathrm{~Gb}$ & $28.94 \pm 0.62 \mathrm{~Gb}$ \\
\hline & 45 & $89.03 \pm 0.71 \mathrm{Aa}$ & $56.48 \pm 0.74 \mathrm{Bb}$ & $48.42 \pm 0.72 \mathrm{Ca}$ & $45.13 \pm 0.39 \mathrm{Db}$ & $40.74 \pm 0.38 \mathrm{~Eb}$ & $36.72 \pm 0.57 \mathrm{Fb}$ & $30.42 \pm 0.99 \mathrm{~Gb}$ & $29.30 \pm 0.41 \mathrm{~Gb}$ \\
\hline & 60 & $89.71 \pm 1.29 \mathrm{Aa}$ & $59.64 \pm 0.65 \mathrm{Ba}$ & $50.83 \pm 0.51 \mathrm{Ca}$ & $50.43 \pm 0.74 \mathrm{Ca}$ & $45.32 \pm 0.74 \mathrm{Da}$ & $39.92 \pm 0.46 \mathrm{Ea}$ & $34.82 \pm 0.40 \mathrm{Fa}$ & $34.29 \pm 0.33 \mathrm{Fa}$ \\
\hline
\end{tabular}

Values with the same letter are not statistically different, according to Duncan's multiple range test at $p<0.05$. a, b, c: mean values with the same letter in the same column are not significantly different. $(p>0.05)(n=8)$. A, B, C, D: mean values with the same letter in the same row are not significantly different. $(p>0.05)(n=8)$ 


\section{References}

1. Abazari, R.; Sanati, S.; Saghatforoush, L.A. Non-aggregated divanadium pentoxide nanoparticles: A one-step facile synthesis. Morphological, structural, compositional, optical properties and photocatalytic activities. Chem. Eng. J. 2014, 236, 82-90. [CrossRef]

2. Taleb, M.F.A.; El-Mohdy, H.L.A.; El-Rehim, H.A.A. Radiation preparation of PVA/CMC copolymers and their application in removal of dyes. J. Hazard. Mater. 2009, 168, 68-75. [CrossRef] [PubMed]

3. Yang, J.; Zheng, Y.; Sheng, L.; Chen, H.; Zhao, L.; Yu, W.; Zhao, K.-Q.; Hu, P. Water Induced Shape Memory and Healing Effects by Introducing Carboxymethyl Cellulose Sodium into Poly (vinyl alcohol). Ind. Eng. Chem. Res. 2018, 57, 15046-15053. [CrossRef]

4. Hallaji, H.; Keshtkar, A.R.; Moosavian, M.A. A novel electrospun PVA/ZnO nanofiber adsorbent for U(VI), $\mathrm{Cu}(\mathrm{II})$ and $\mathrm{Ni}(\mathrm{II})$ removal from aqueous solution. J. Taiwan Inst. Chem. Eng. 2015, 46, 109-118. [CrossRef]

5. Abutalib, M.M. Effect of zinc oxide nanorods on the structural, thermal, dielectric and electrical properties of polyvinyl alcohol/carboxymethyle cellulose composites. Phys. B Condens. Matter 2019, 557, 108-116. [CrossRef]

6. El Sayed, A.M.; El-Gamal, S.; Morsi, W.M.; Mohammed, G. Effect of PVA and copper oxide nanoparticles on the structural, optical, and electrical properties of carboxymethyl cellulose films. J. Mater. Sci. 2015, 50, 4717-4728. [CrossRef]

7. Zhong, R.; Zhong, Q.; Huo, M.; Yang, B.; Li, H. Preparation of biocompatible nano-ZnO/chitosan microspheres with multi-functions of antibacterial, UV-shielding and dye photodegradation. Int. J. Biol. Macromol. 2020, 146, 939-945. [CrossRef]

8. Espitia, P.J.P.; Soares, N.D.F.F.; dos Reis Coimbra, J.S.; de Andrade, N.J.; Cruz, R.S.; Medeiros, E.A.A. Zinc Oxide Nanoparticles: Synthesis, Antimicrobial Activity and Food Packaging Applications. Food Bioprocess Technol. 2012, 5, 1447-1464. [CrossRef]

9. Zhou, T.-J.; Hu, Y.-Y.; Chen, R.-Y.; Zheng, X.; Chen, X.; Chen, Z.; Zhong, J.-Q. Preparation and characterization of bipolar membranes modified by photocatalyst nano- $\mathrm{ZnO}$ and nano- $\mathrm{CeO}_{2}$. Appl. Surf. Sci. 2012, 258, 4023-4027. [CrossRef]

10. Parameswaranpillai, J.; Sanjay, M.R.; Varghese, S.A.; Siengchin, S.; Jose, S.; Salim, N.; Hameed, N.; Magueresse, A. Toughened PS/LDPE/SEBS/xGnP ternary composites: Morphology, mechanical and viscoelastic properties. Int. J. Light. Mater. Manuf. 2019, 2, 64-71. [CrossRef]

11. Asrofi, M.; Abral, H.; Kasim, A.; Pratoto, A.; Mahardika, M.; Hafizulhaq, F. Mechanical Properties of a Water Hyacinth Nanofiber Cellulose Reinforced Thermoplastic Starch Bionanocomposite: Effect of Ultrasonic Vibration during Processing. Fibers 2018, 6, 40. [CrossRef]

12. Wang, R.; Ma, N.; Yan, Y.; Wang, Z. Ultrasonic-assisted fabrication of high flux T-type zeolite membranes on alumina hollow fibers. J. Membr. Sci. 2018, 548, 676-684. [CrossRef]

13. Asrofi, M.; Abral, H.; Putra, Y.K.; Sapuan, S.M.; Kim, H.-J. Effect of duration of sonication during gelatinization on properties of tapioca starch water hyacinth fiber biocomposite. Int. J. Biol. Macromol. 2018, 108, 167-176. [CrossRef] [PubMed]

14. Liu, Y.; Wang, S.; Lan, W.; Qin, W. Development of ultrasound treated polyvinyl alcohol/tea polyphenol composite films and their physicochemical properties. Ultrason. Sonochem. 2019, 51, 386-394. [CrossRef]

15. Yan, Y.; Duan, S.; Zhang, H.; Liu, Y.; Li, C.; Hu, B.; Liu, A.; Wu, D.; He, J.; Wu, W. Preparation and characterization of Konjac glucomannan and pullulan composite films for strawberry preservation. Carbohydr. Polym. 2020, 243, 116446. [CrossRef]

16. Abdeen, Z.I.; El Farargy, A.F.; Negm, N.A. Nanocomposite framework of chitosan/polyvinyl alcohol/ZnO: Preparation, characterization, swelling and antimicrobial evaluation. J. Mol. Liq. 2018, 250, 335-343. [CrossRef]

17. Swaroop, K.; Somashekarappa, H.M. In vitro Biocompatibility and Antibacterial Activity of Gamma Ray Crosslinked ZnO/PVA Hydrogel Nanocomposites. Mater. Today Proc. 2018, 5, 21314-21321. [CrossRef]

18. Zhao, Z.; Mao, A.; Gao, W.; Bai, H. A facile in situ method to fabricate transparent, flexible polyvinyl alcohol/ZnO film for UV-shielding. Compos. Commun. 2018, 10, 157-162. [CrossRef]

19. Saadiah, M.A.; Zhang, D.; Nagao, Y.; Muzakir, S.K.; Samsudin, A.S. Reducing crystallinity on thin film based CMC/PVA hybrid polymer for application as a host in polymer electrolytes. J. Non-Cryst. Solids 2019, 511, 201-211. [CrossRef] 
20. Sun, L.; Sun, J.; Chen, L.; Niu, P.; Yang, X.; Guo, Y. Preparation and characterization of chitosan film incorporated with thinned young apple polyphenols as an active packaging material. Carbohydr. Polym. 2017, 163, 81-91. [CrossRef]

21. ASTM E96/E96M-16. Standard Test Methods for Water Vapor Transmission of Materials; ASTM International: West Conshohocken, PA, USA, 2016.

22. ASTM. Standard test methods for tensile properties of thin plastic sheeting. D882-10. In Annual Book of ASTM.; American Society for testing and Materials: Philadelphia, PA, USA, 2010.

23. Khorasani, M.T.; Joorabloo, A.; Moghaddam, A.; Shamsi, H.; MansooriMoghadam, Z. Incorporation of ZnO nanoparticles into heparinised polyvinyl alcohol/chitosan hydrogels for wound dressing application. Int. J. Biol. Macromol. 2018, 114, 1203-1215. [CrossRef]

24. Arfat, Y.A.; Benjakul, S.; Prodpran, T.; Sumpavapol, P.; Songtipya, P. Properties and antimicrobial activity of fish protein isolate/fish skin gelatin film containing basil leaf essential oil and zinc oxide nanoparticles. Food Hydrocoll. 2014, 41, 265-273. [CrossRef]

25. Zhang, R.; Wang, Y.; Ma, D.; Ahmed, S.; Qin, W.; Liu, Y. Effects of ultrasonication duration and graphene oxide and nano-zinc oxide contents on the properties of polyvinyl alcohol nanocomposites. Ultrason. Sonochem. 2019, 59, 104731. [CrossRef] [PubMed]

26. Gao, Y.; Xu, D.; Ren, D.; Zeng, K.; Wu, X. Green synthesis of zinc oxide nanoparticles using Citrus sinensis peel extract and application to strawberry preservation: A comparison study. LWT 2020, 126, 109297. [CrossRef]

27. Khodaei, D.; Hamidi-Esfahani, Z. Influence of bioactive edible coatings loaded with Lactobacillus plantarum on physicochemical properties of fresh strawberries. Postharvest. Biol. Technol. 2019, 156, 110944. [CrossRef]

28. Abral, H.; Atmajaya, A.; Mahardika, M.; Hafizulhaq, F.; Handayani, D.; Sapuan, S.M.; Ilyas, R.A. Effect of ultrasonication duration of polyvinyl alcohol (PVA) gel on characterizations of PVA film. J. Mater. Res. Technol. 2020, 9, 2477-2486. [CrossRef]

29. Agarwal, R.; Alam, M.S.; Gupta, B. Polyvinyl alcohol-polyethylene oxide-carboxymethyl cellulose membranes for drug delivery. J. Appl. Polym. Sci. 2013, 129, 3728-3736. [CrossRef]

30. Fasihi, H.; Fazilati, M.; Hashemi, M.; Noshirvani, N. Novel carboxymethyl cellulose-polyvinyl alcohol blend films stabilized by Pickering emulsion incorporation method. Carbohydr. Polym. 2017, 167, 79-89. [CrossRef]

31. Koutavarapu, R.; Manepalli, R.K.N.R.; Madhav, B.T.P.; Satyanarayana, T.; Nagarjuna, G.; Shim, J.; Rao, M.C. Optical, electrical and photoluminescence studies on $\mathrm{Al}_{2} \mathrm{O}_{3}$ doped PVA capped $\mathrm{ZnO}$ nanoparticles for optoelectronic device application. Optik 2020, 205, 164236. [CrossRef]

32. Bouakaz, B.S.; Habi, A.; Grohens, Y.; Pillin, I. Organomontmorillonite/graphene-PLA/PCL nanofilled blends: New strategy to enhance the functional properties of PLA/PCL blend. Appl. Clay Sci. 2017, 139, 81-91. [CrossRef]

33. Özkan, V.; Yapici, A.; Karaaslan, M.; Akgöl, O. Electromagnetic Scattering Properties of MWCNTs/Graphene Doped Epoxy Layered with PVC Nanofiber/E-Glass Composites. J. Electron. Mater. 2020, 49, 2249-2256. [CrossRef]

34. Chilkoor, G.; Sarder, R.; Islam, J.; ArunKumar, K.E.; Ratnayake, I.; Star, S.; Jasthi, B.K.; Sereda, G.; Koratkar, N.; Meyyappan, M.; et al. Maleic anhydride-functionalized graphene nanofillers render epoxy coatings highly resistant to corrosion and microbial attack. Carbon 2020, 159, 586-597. [CrossRef]

35. Akhavan, A.; Khoylou, F.; Ataeivarjovi, E. Preparation and characterization of gamma irradiated Starch/PVA/ZnO nanocomposite films. Radiat. Phys. Chem. 2017, 138, 49-53. [CrossRef]

36. Shtepliuk, I.; Ivanov, I.G.; Pliatsikas, N.; Iakimov, T.; Jamnig, A.; Sarakinos, K.; Yakimova, R. Probing the uniformity of silver-doped epitaxial graphene by micro-Raman mapping. Phys. B Condens. Matter 2020, 580, 411751. [CrossRef]

37. Abdelwahab, N.A.; Ghoneim, A.M. Photocatalytic activity of ZnO coated magnetic crosslinked chitosan/polyvinyl alcohol microspheres. Mater. Sci. Eng. B 2018, 228, 7-17. [CrossRef]

38. Isa, M.I.N.; Samsudin, A.S. Structural and Ionic Transport Study on CMC Doped NH4Br: A New Types of Biopolymer Electrolytes. J. Appl. Sci. 2012, 12, 174-179. [CrossRef]

39. Hemalatha, K.S.; Rukmani, K.; Suriyamurthy, N.; Nagabhushana, B.M. Synthesis, characterization and optical properties of hybrid PVA-ZnO nanocomposite: A composition dependent study. Mater. Res. Bull. 2014, 51, 438-446. [CrossRef] 
40. Chieng, B.W.; Ibrahim, N.A.; Yunus, W.M.Z.W.; Hussein, M.Z.; Loo, Y.Y. Effect of graphene nanoplatelets as nanofiller in plasticized poly(lactic acid) nanocomposites. J. Therm. Anal. Calorim. 2014, 118, 1551-1559. [CrossRef]

41. Goswami, A.; Bajpai, A.K.; Bajpai, J.; Sinha, B.K. Designing vanadium pentoxide-carboxymethyl cellulose/polyvinyl alcohol-based bionanocomposite films and study of their structure, topography, mechanical, electrical and optical behavior. Polym. Bull. 2017, 75, 781-807. [CrossRef]

42. Lefatshe, K.; Muiva, C.M.; Kebaabetswe, L.P. Extraction of nanocellulose and in-situ casting of ZnO/cellulose nanocomposite with enhanced photocatalytic and antibacterial activity. Carbohydr. Polym. 2017, 164, 301-308. [CrossRef]

43. Chieng, B.W.; Ibrahim, N.A.; Yunus, W.M.; Hussein, M.Z.; Silverajah, V.S.G. Graphene nanoplatelets as novel reinforcement filler in poly(lactic acid)/epoxidized palm oil green nanocomposites: Mechanical properties. Int. J. Mol. Sci. 2012, 13, 10920-10934. [CrossRef] [PubMed]

44. Bai, Q.-Q.; Wei, X.; Yang, J.-H.; Zhang, N.; Huang, T.; Wang, Y.; Zhou, Z.-W. Dispersion and network formation of graphene platelets in polystyrene composites and the resultant conductive properties. Compos. Part $A$ Appl. Sci. Manuf. 2017, 96, 89-98. [CrossRef]

45. Kochkina, N.E.; Butikova, O.A. Effect of fibrous TiO2 filler on the structural, mechanical, barrier and optical characteristics of biodegradable maize starch/PVA composite films. Int. J. Biol. Macromol. 2019, 139, 431-439. [CrossRef] [PubMed]

46. El-Sayed, S.; Mahmoud, K.H.; Fatah, A.A.; Hassen, A. DSC, TGA and dielectric properties of carboxymethyl cellulose/polyvinyl alcohol blends. Phys. B Condens. Matter 2011, 406, 4068-4076. [CrossRef]

47. Chakraborty, G.; Valapa, R.B.; Pugazhenthi, G.; Katiyar, V. Investigating the properties of poly (lactic acid)/exfoliated graphene based nanocomposites fabricated by versatile coating approach. Int. J. Biol. Macromol. 2018, 113, 1080-1091. [CrossRef]

48. Girdthep, S.; Komrapit, N.; Molloy, R.; Lumyong, S.; Punyodom, W.; Worajittiphon, P. Effect of plate-like particles on properties of poly(lactic acid)/poly(butylene adipate-co-terephthalate) blend: A comparative study between modified montmorillonite and graphene nanoplatelets. Compos. Sci. Technol. 2015, 119, 115-123. [CrossRef]

49. Rodríguez-Tobías, H.; Morales, G.; Grande, D. Improvement of mechanical properties and antibacterial activity of electrospun poly(d, l-lactide)-based mats by incorporation of $\mathrm{ZnO}$ - graft -poly(d, l-lactide) nanoparticles. Mater. Chem. Phys. 2016, 182, 324-331. [CrossRef]

50. Scaffaro, R.; Botta, L.; Maio, A.; Gallo, G. PLA graphene nanoplatelets nanocomposites: Physical properties and release kinetics of an antimicrobial agent. Compos. Part B Eng. 2017, 109, 138-146. [CrossRef]

51. Zhou, Y.G.; Zhao, X.D.; Dong, B.B.; Liu, C.T. Improvement of the dispersity of micro-nano particles for $\mathrm{PP} / \mathrm{PVC}$ composites using gas-assisted dispersion in a controlled foaming process. Polym. Eng. Sci. 2019, 60, 524-534. [CrossRef]

52. Wang, J.; Zhang, W.; Yin, Q.; Yin, B.; Jia, H. Highly sensitive and flexible strain sensors based on natural rubber/graphene foam composites: The role of pore sizes of graphene foam. J. Mater. Sci. Mater. Electron. 2019, 31, 125-133. [CrossRef]

53. Ranjan, S.; Mukherjee, B.; Islam, A.; Pandey, K.K.; Gupta, R.; Keshri, A.K. Microstructure, mechanical and high temperature tribological behaviour of graphene nanoplatelets reinforced plasma sprayed titanium nitride coating. J. Eur. Ceram. Soc. 2020, 40, 660-671. [CrossRef]

54. Abral, H.; Putra, G.J.; Asrofi, M.; Park, J.-W.; Kim, H.-J. Effect of vibration duration of high ultrasound applied to bio-composite while gelatinized on its properties. Ultrason. Sonochem. 2018, 40, 697-702. [CrossRef] [PubMed]

55. Cheng, W.; Chen, J.; Liu, D.; Ye, X.; Ke, F. Impact of ultrasonic treatment on properties of starch film-forming dispersion and the resulting films. Carbohydr. Polym. 2010, 81, 707-711. [CrossRef]

56. Gao, Y.; Jing, H.W.; Chen, S.J.; Du, M.R.; Chen, W.Q.; Duan, W.H. Influence of ultrasonication on the dispersion and enhancing effect of graphene oxide-carbon nanotube hybrid nanoreinforcement in cementitious composite. Compos. Part B Eng. 2019, 164, 45-53. [CrossRef]

57. Peres, G.L.; Leite, D.C.; Silveira, N.P.D. Ultrasound effect on molecular weight reduction of amylopectin. Starch-Stärke 2015, 67, 407-414. [CrossRef] 
58. Wang, D.; Lv, R.; Ma, X.; Zou, M.; Wang, W.; Yan, L.; Ding, T.; Ye, X.; Liu, D. Lysozyme immobilization on the calcium alginate film under sonication: Development of an antimicrobial film. Food Hydrocoll. 2018, 83, 1-8.B. [CrossRef]

59. Han, W.; Wu, Z.; Li, Y.; Wang, Y. Graphene family nanomaterials (GFNs)_Promising materials for antimicrobial coating and film: A review. Chem. Eng. J. 2019, 358, 1022-1037. [CrossRef]

60. Akhavan, O.; Ghaderi, E. Toxicity of graphene and graphene oxide nanowalls against bacteria. ACS Nano 2010, 4, 5731-5736. [CrossRef]

61. Heydari-Majd, M.; Ghanbarzadeh, B.; Shahidi-Noghabi, M.; Najafi, M.A.; Hosseini, M. A new active nanocomposite film based on PLA/ZnO nanoparticle/essential oils for the preservation of refrigerated Otolithes ruber fillets. Food Packag. Shelf Life 2019, 19, 94-103. [CrossRef]

62. Panea, B.; Ripoll, G.; González, J.; Fernández-Cuello, Á.; Albertí, P. Effect of nanocomposite packaging containing different proportions of $\mathrm{ZnO}$ and $\mathrm{Ag}$ on chicken breast meat quality. J. Food Eng. 2014, 123, 104-112. [CrossRef]

63. Deepa, B.; Abraham, E.; Pothan, L.A.; Cordeiro, N.; Faria, M.; Thomas, S. Biodegradable Nanocomposite Films Based on Sodium Alginate and Cellulose Nanofibrils. Materials 2016, 9, 50. [CrossRef] [PubMed]

64. Salehpour, S.; Jonoobi, M.; Ahmadzadeh, M.; Siracusa, V.; Rafieian, F.; Oksman, K. Biodegradation and ecotoxicological impact of cellulose nanocomposites in municipal solid waste composting. Int. J. Biol. Macromol. 2018, 111, 264-270. [CrossRef] [PubMed]

65. Lani, N.S.; Ngadi, N.; Johari, A.; Jusoh, M. Isolation, Characterization, and Application of Nanocellulose from Oil Palm Empty Fruit Bunch Fiber as Nanocomposites. J. Nanomater. 2014, 2014, 702538. [CrossRef]

(C) 2020 by the authors. Licensee MDPI, Basel, Switzerland. This article is an open access article distributed under the terms and conditions of the Creative Commons Attribution (CC BY) license (http://creativecommons.org/licenses/by/4.0/). 